\title{
Effect of meteorological and hydrographic disturbances on the microplankton community structure in the Ría de Vigo (NW Spain)
}

\author{
E. Nogueiraa ${ }^{1, *}$, F. Ibanez ${ }^{2}$, F. G. Figueiras ${ }^{1}$ \\ ${ }^{1}$ Instituto de Investigacións Mariñas, CSIC, Eduardo Cabello, 6, 36208 Vigo, Spain \\ 2 Observatoire Océanologique, Laboratoire d'Océanographie Biologique et Ecologie du Plancton Marin, \\ CNRS ESA 7076, BP 28, 06230 Villefranche-sur-Mer, France
}

\begin{abstract}
The relationships between meteorological and hydrographic disturbances and microplankton community structure and organisation were investigated in the Ría de Vigo, an estuarine ecosystem affected by coastal upwelling. The frequency and duration of sampling (ca twice per week from September 1990 to May 1992) are appropriate to reveal the impact of disturbances in the context of the seasonal cycle. Perturbations were identified statistically and related to recognisable meteorological and hydrographic processes that are expected to influence microplankton dynamics. According to the frequency of disturbances (between 8 and $14 \mathrm{yr}^{-1}$ ) the ecosystem could be classified as intermediate-frequency disturbed in relation to the microplankton community organisation timescales. Meteorological and thermohaline disturbances promoted changes in microplankton community structure (disjunctions). The time-series of thermohaline properties, a proxy for allogenic processes related with mixing regimes and estuarine circulation, was the best indicator of changes in community structure: 15 out of the 21 disjunctions (ca $70 \%$ ) coincided with thermohaline disturbances. Disturbances of the nutrient fields were related to allogenic forcing but also, markedly during the productive season, to re-structuring of the microplankton community. They pointed out autogenic community-driven processes. Microplankton assemblages revealed by the species-oriented ordination technique were interpreted in terms of the replication strategies: well-defined groups of competitor (C), disturbance-tolerant ruderal (R) and stress-tolerant (S) species were discerned. At a seasonal time-scale, succession progressed according to the sequence from $\mathrm{r}$ - to K-selection strategies. C-species dominated spring assemblages, during the period of transient thermoclines, while Sspecies contributed more to summer assemblages, when the thermocline was fully developed and the ecosystem was under nutrient stress. R-species showed an intermittent pattern and their relative abundance increased when environmental variability was more acute, during the winter and spring to summer (clear-water phase) transition. The regime of allogenic disturbances operating at intermediate frequency during the productive season allowed the maintenance of relatively high microplankton diversity at the functional (assemblage) level: all types of replication strategies were present during summer and early autumn. The results support the applicability of the intermediate disturbance hypothesis (IDH) to microplankton community structure in the Ría de Vigo.
\end{abstract}

KEY WORDS: Disturbances - Microplankton community structure $\cdot$ Replication strategies $\cdot$ Intermediate disturbance hypothesis (IDH) · Ría de Vigo

Resale or republication not permitted without written consent of the publisher

\section{INTRODUCTION}

The seasonal succession of plankton rarely proceeds smoothly: the progress towards climax driven by self-

\footnotetext{
*Present address: Imperial College of Science, Technology and Medicine, RSM, Prince Consort Road, London SW7 2BP, United Kingdom. E-mail: e.nogueira@ic.ac.uk
}

imposed (autogenic) processes is frustrated by disturbances, which delay, arrest or divert successional sequences (Reynolds 1993, 1997). Whatever the relevance of the concept of disturbance as an important determining factor of ecosystem structure and processes, its definition is still muddled and there are some difficulties concerning the identification and characterisation of disturbances (Reynolds et al. 1993). 
The formal ecological definition (Picket et al. 1989) states that an ecological disturbance is a discrete event that changes the structure of the community. According to this definition, the nature of the disturbance, which is generally imposed from outside the system (allogenic disturbance), is evaluated by the reaction it promotes, and its characterisation will depend upon the perception of the structure of the ecological system concerned (Reynolds et al. 1993). This results in a tautological argument (Sommer et al. 1993) and raises problems for the discernment of some important phenomena associated with ecological succession (Margalef 1961, 1968, Odum 1969). In the present paper, we followed the definition proposed by Reynolds et al. (1993), and the term disturbance applies to any major change in some of the meteorological and hydrographic variables relevant to microplankton dynamics.

The selection of different replication strategies, one of the phenomena associated with microplankton succession, has important consequences for the ecosystem pathways of energy and matter (Cushing 1989, Legendre \& Rassoulzadegan 1996). Within any given community it is possible to identify a spectrum of replication strategies (Pianka 1970), from the r-strategists, characterised by their capacity to build populations quickly by investing in growth rate, to the K-strategists, which optimise, through different adaptive mechanisms, for low loss rates. Concerning marine microplankton, Margalef (1958) was the first to discern the relationship between the major sources of hydrographic characterisation and variability (mixing and nutrient status) and the selection of replication strategies. He distinguished 3 basic types of marine phytoplankton assemblages: (I) small-celled diatoms, characteristic of highly turbulent conditions; (II) bitter diatoms (and green flagellates according to Harris 1978), able to cope with intermediate and highly fluctuating environments; and (III) dinoflagellates, adapted to exploit stratified environments. Groups I and III are typical representatives of $\mathrm{r}$ - and K-strategists respectively. In an attempt to unify concepts according to the general findings relative to plant strategies and vegetation processes (Grime 1979), these groups were re-defined by Reynolds (1997), who proposed the terms C-, S- and R-species (approximate equivalents to Margalef's Groups I, III and II respectively).

C-species (competitors) are 'invasive' strategists able to exploit the onset of new hydrographic conditions. This group is composed of small, single-cell organisms with high surface $(s)$ to volume $(v)$ ratios $\left(s \cdot V^{-1}\right.$ between 0.7 and $1.8 \mu^{-1}$ ), which facilitates rapid nutrient absorption, assimilation and replication (Kiørboe 1995). Cell replication rates at $20^{\circ} \mathrm{C}(r)$ are between 1 and $2 \mathrm{~d}^{-1}$ (Cushing 1989) and remain relatively high at low temperatures (Reynolds 1997). At the other extreme, S-species (stress-tolerant) are 'acquisitive' strategists characteristic of stratified conditions. They are typically large single cells $\left(v>10^{4} \mu^{3}\right)$ or colonyforming, small cells able to alter their vertical position in the water column by means of swimming motion or buoyancy control. Their distinctively low $S V^{-1}$ $\left(<0.3 \mu^{-1}\right)$ imply low nutrient and light-harvesting efficiency and low replication rates $\left(r<0.4 \mathrm{~d}^{-1}\right)$, but their characteristic large size may provide a refuge from predation (Kiørboe 1991). Finally, R-species (ruderals) are 'attuning' strategists, either tolerant or dependent on fluctuating environmental perturbations. Their pre-adaptations, such as elongated or trichal morphology, maximise their suspension in the water column and provide a relatively high $s V^{-1}$ (between 0.4 and $1.0 \mathrm{~mm}^{-1}$ ), thus enabling relatively high nutrient and light-harvesting efficiency, and high replication rates ( $r$ between 0.6 and $1.0 \mathrm{~d}^{-1}$ ). Typical representatives include both $\mathrm{r}$ - and K-strategist species.

The generation times provide the critical time-scale for a correct interpretation of microplankton succession (Reynolds 1993). The generation times must in turn be related with the characteristic time-scales of environmental variability (Lewis \& Platt 1982), especially relevant in estuaries since they are among the most complex and dynamic ecosystems (Kjerfve et al. 1982). The relationship between the generation times and the characteristic time-scales of environmental variability lies at the core of different theories of community structure (Harris 1986). According to the intermediate disturbance hypothesis (IDH) (Connell 1978), a non-equilibrium theory, the diversity of the microplankton community reaches a maximum when disturbances occur at intermediate frequency (between 8 and $50 \mathrm{yr}^{-1}$ ) (Reynolds 1997). In this frequency range competitive exclusion is avoided, and therefore $\mathrm{r}$ - and K-selected species can co-exist (Pádisak et al. 1993, Reynolds et al. 1993).

The number of investigations dealing with the effect of disturbances on phytoplankton succession and related phenomena are far more abundant for freshwater (e.g. all contributions in Hydrobiologia 249, 1993, Lindenschmidt \& Chorus 1998) than for marine ecosystems (e.g. Blasco et al. 1980, Karentz \& Smayda $1988,1998)$. The study of microplankton succession in the Ría de Vigo began with the classical studies from Margalef and co-workers (Margalef et al. 1955). Some recent studies of microplankton succession and its relation with environmental factors in this estuarine ecosystem affected by coastal upwelling support the main aspects of the succession suggested by Margalef (e.g. Figueiras \& Ríos 1993). These studies were conducted during long-term periods $(\geq 1 \mathrm{yr})$ at low sampling frequency $\left(<1 \mathrm{wk}^{-1}\right)$, thus focusing mainly on 
seasonal succession (e.g. Margalef et al. 1955), or during short-term periods ( 2 to $20 \mathrm{~d}$ ) at high sampling frequency $\left(\geq 2 \mathrm{wk}^{-1}\right.$ ) (e.g. Figueiras et al. 1994), thus dealing with event-scale microplankton dynamics. However, none of the studies conducted in the Ría de Vigo (or the other rías of NW Spain) has analysed explicitly the role of disturbances.

We investigated the response of microplankton community structure to meteorological and hydrographic disturbances in the Ría de Vigo. The sampling frequency $\left(\sim 2 \mathrm{wk}^{-1}\right)$ and extent (20 mo, from September 1990 to April 1992) are suitable to evaluate this response according to microplankton generation times in the context of the seasonal succession. Our objectives were: to detect and characterise disturbances in different environmental time-series relevant to microplankton dynamics; to identify disjunctions in microplankton succession and to assess their relationships with disturbances; and, finally, to analyse temporal changes in microplankton community structure (at the assemblage level) at seasonal and disturbance time-scales. The results were discussed in the framework of the IDH.

\section{MATERIAL AND METHODS}

Hydrography of the survey area. The Rías Baixas, 4 flooded tectonic valleys on the NW Iberian Peninsula (Fig. 1), have been the focus of numerous hydrographic studies (references in Fraga 1996). Hydrodynamically, the Rías behave as partially mixed estuaries with a 2-layered positive residual circulation pattern (Fraga 1981). Since they are located on the northern boundary $\left(42\right.$ to $43^{\circ} \mathrm{N}$ ) of the NW Africa upwelling system (Wooster et al. 1976), their circulation is strongly influenced by coastal upwelling dynamics (Fraga 1981). In a simplified description of the process, northerly winds over the adjacent shelf promote upwelling, and therefore the bottom inflow of cold, nutrient-rich, sub-surface oceanic Eastern North Atlantic Central Water (ENACW) into the Rías, and the enhancement of the positive residual circulation. Conversely, southerly winds promote coastal downwelling, and thus the surface inflow of surface oceanic water with relatively high thermohaline variability and low nutrient content. Coastal downwelling causes the slow-down or even reversal of the circulation pattern. Upwelling dynamics over the adjacent shelf play a major role in the circulation (e.g. Rosón et al. 1997), biogeochemical features (e.g. Álvarez-Salgado et al. 1996) and microplankton dynamics (e.g. Figueiras et al. 1994) of the Rías.

Time-series. The period analysed here covers $20 \mathrm{mo}$, from September 1990 to April 1992. Hydrographic and

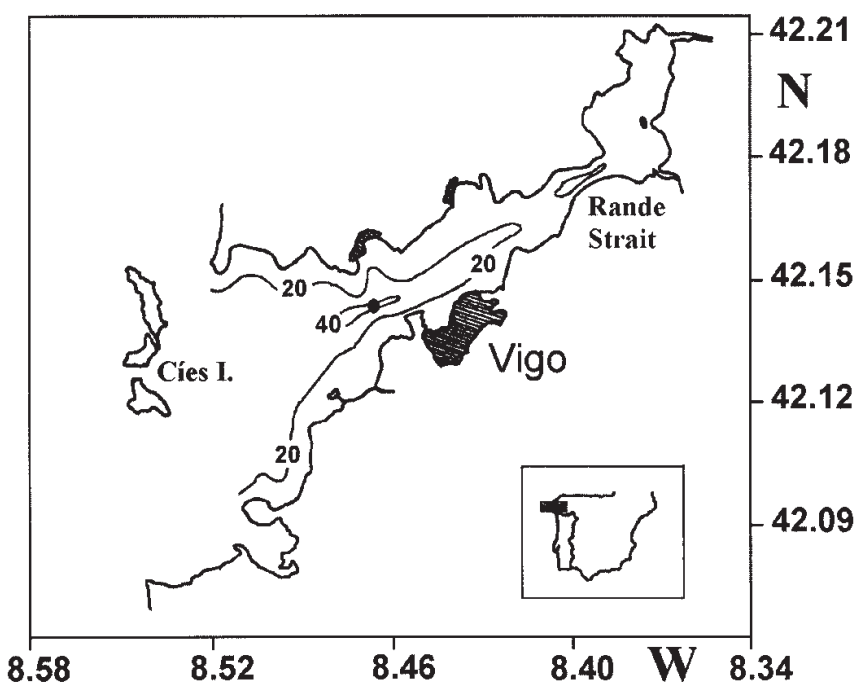

Fig. 1. Map of the Ría de Vigo showing the position of the hydrographic time-series station

microplankton sampling was carried out in the middle zone and in the main channel of the Ría de Vigo (Fig. 1), the southernmost of the Rías Baixas. The sampling interval was variable, between 2 and $4 \mathrm{~d}$ most of the time. The sampling depths were 1 and $15 \mathrm{~m}$ for microplankton plus an additional sampling at $40 \mathrm{~m}$ for hydrography. Daily averages of the cross-shore (upwelling index) and along-shore Ekman transports, incoming solar radiation and runoff were the meteorological variables analysed. Table 1 gives a summary of the variables, symbols, units and methodology used.

Numerical analysis. The numerical methods applied to the meteorological and hydrographic time-series focused in the detection of environmental disturbances. Those applied to the microplankton abundance data aimed to determine the discontinuities (disjunctions) in the multivariate (multi-species) timeseries (Q-mode analysis, i.e. samples-oriented), and to evaluate species associations (i.e. statistical communities or assemblages) characteristics of the ecosystem in the analysed period (R-mode analysis, i.e. speciesoriented). The steps of the numerical analysis are schematised in Fig. 2.

Meteorological and hydrographic time-series: Step 1. Sampling interval regularisation: Since the $D^{2}$ to the centroid method (Step 2, Fig. 2) requires a time-series of regular sampling interval (Ibanez 1981), the hydrographic time-series were interpolated by a thirdorder polynomial spline function (Lancaster \& Salkaukas 1986) to obtain values for identical time intervals of $3 \mathrm{~d}$.

Step 2. Detection of environmental disturbances: Disturbances were identified by the $D^{2}$ to the centroid method (Ibanez 1981). This multivariate technique 


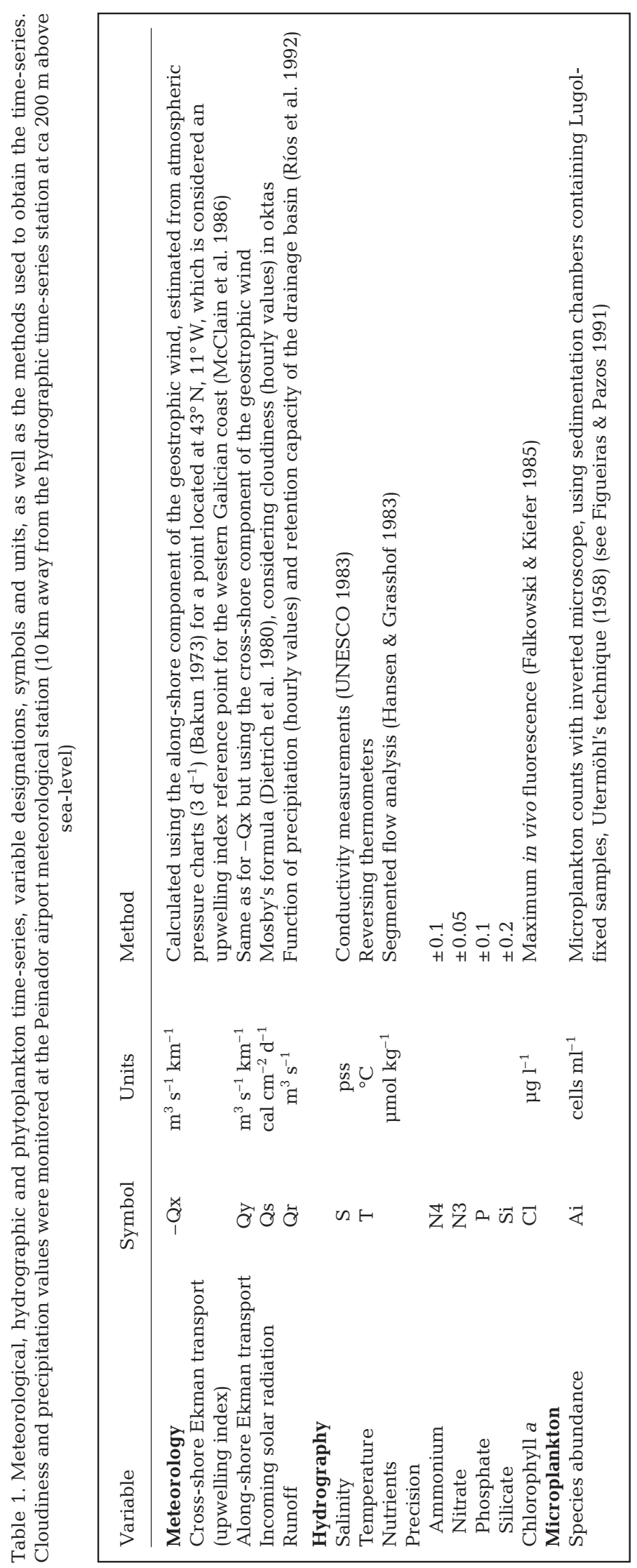

identifies points of maximal change in a multivariate time-series. At every sampling point the generalised distance of Mahalanobis' $D^{2}$ is computed between the new multivariate observation and the centroid of $n$ previously recorded observations,

$$
D^{2}=\left(\boldsymbol{X}_{i}-\overline{\boldsymbol{X}}\right)^{\prime} \boldsymbol{S}^{-1}\left(\boldsymbol{X}_{i}-\overline{\boldsymbol{X}}\right)
$$

where $\boldsymbol{X}_{i}$ is the vector of the co-ordinates of the point $x_{i}$ in the hyper-space of $p$ descriptors, $\overline{\boldsymbol{X}}$ is the vector of the co-ordinates of the centroid (i.e. mean point of co-ordinates in the chosen window of $n$ observations), and $\boldsymbol{S}^{-1}$ is the inverse of the variance-covariance matrix of the descriptors. $D^{2}$ takes into account the variation in the range of the descriptors and their correlations.

The calculus was performed with standardised descriptors (0 mean and unit variance) in order to eliminate the differences in variance, and thus $\boldsymbol{S}^{-1}$ becomes the inverse of the correlation matrix, $\boldsymbol{R}^{-1}$ :

$$
D^{2}=\boldsymbol{X}_{i}{ }^{\prime} \boldsymbol{R}^{-1} \boldsymbol{X}_{i}
$$

Cooley \& Lohnes (1962) have shown that the $D^{2}$ corresponds to a $K^{2}$ distribution with p degrees of freedom. If the value of $D^{2}$ is higher than $K^{2}$ for $p$ degrees of freedom at the $5 \%$ level, the null hypothesis is rejected: the observation $x_{i}$ does not belong to the population of $n$ samples, and it is considered a disturbance.

The algorithm is progressive, starting from a given window width and then moving 1 sampling unit forward, eliminating the first observation, until the last observation in the series is considered. The choice of the window width is critical since it defines the observational band for the detection of disturbances. The only method to objectively detect the appropriate window width is to consider the auto- $D^{2}$ function (Ibanez 1976, 1981). The calculation of the auto- $D^{2}$ function is carried out similarly to the auto-correlation function. The distance between the multivariate series with itself is estimated and then moved successively 1 unit of sampling interval forward, to the maximum of $T / 2$, where $T$ is the total number of observations. For a lag $\theta$,

$$
\boldsymbol{B}=\frac{1}{T-\theta}\left(\sum_{t=1}^{T-\theta} \boldsymbol{X}_{t}-\sum_{t=\theta+1}^{T} \boldsymbol{X}_{t}\right)
$$

where $\theta=0,1,2, \ldots, T / 2$, and with the first term corresponding to the vector of the averages of a first group of observations from $t$ to $T-\theta$ and the second term corresponding to the vector of the averages of a second group of observations from $\theta+1$ to $T$, 


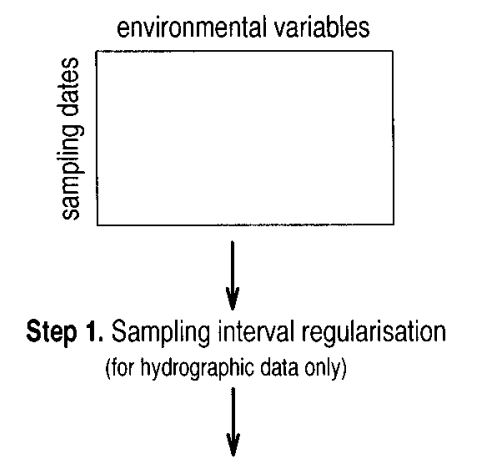

Step 2. Detection of environmental disturbances ( $D^{2}$ to the centroid)

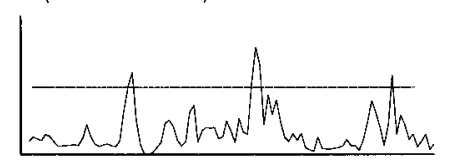

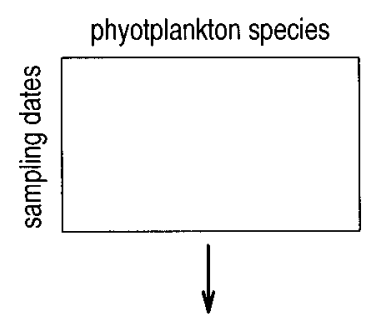

Step 3. Selection of the most representative species

Step 4. Identification of disjunctions in phytoplankton succession (Q-mode analysis; chronological clustering with contiguity constraint) clustering method)
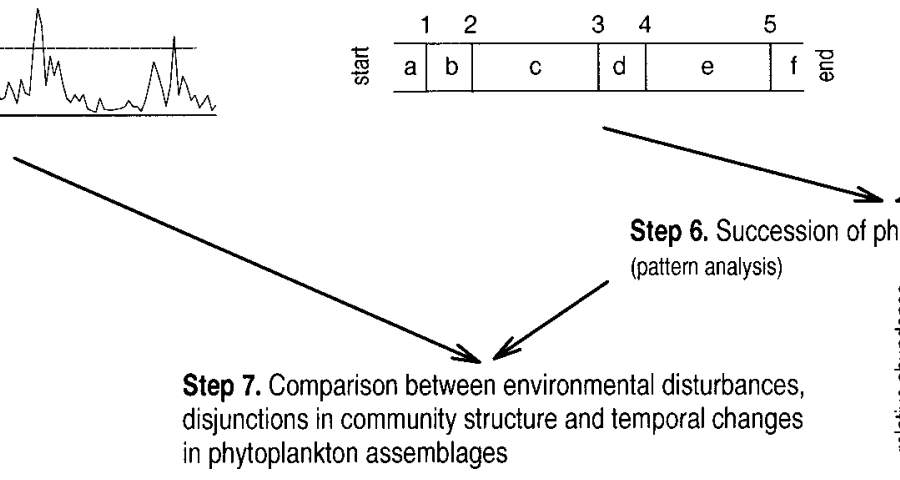
(R-mode analysis: hierarchical flexible 
Microplankton species abundance matrix: Step 3. Selection of the most representative species: The abundance of microplankton species is often very low, and the first problem was to select among the 455 different species observed at least once during the analysed period ( $32 \%$ diatoms, $43 \%$ dinoflagellates, $7 \%$ flagellates and $18 \%$ ciliates) the most representative for the later numerical treatment. A simple histogram method was chosen (Ibanez et al. 1993), where the classes represent the percentage of null values from 0 to $100 \%$ and the absolute frequency is the number of species of such percentage. A change in the slope of the curve separates species with different modes of presence-absence distribution. Species with a percentage of zero below the slope are retained for subsequent analysis. A sharp change in slope in the histograms of surface and middle samples (not shown) was observed around the $30 \%$ class, and therefore those species with $<30 \%$ absence were selected for subsequent analysis. A total of 52 species, the same in surface and middle samples, satisfied the selection criterion (species listed in Fig. 6). They represented ca $82 \%$ of total abundance: 23 species of diatoms, 17 of dinoflagellates, 4 of flagellates and 8 of ciliates $(44,38,8$ and $15 \%$ respectively).

The statistical analyses were applied to the speciesabundance matrices for the surface, middle and the sum of abundance at both depths (sum-matrix). The abundance data were natural-log transformed to preserve the relative differences in magnitude of occurrence (Allen \& Koonce 1973).

Step 4. Detection of disjunctions in microplankton succession: The constrained chronological clustering method (Legendre et al. 1985) was applied to recognise successive homogeneous periods in the multispecies abundance time-series. Unlike others methods that perform the analysis of succession applying some kind of preliminary ordination on reduced space of the multi-species matrix, for instance principal component analysis, the chronological clustering method is based on the original multi-species matrix. The basis of the method corresponds to a proportional link linkage hierarchical clustering with constraint of time contiguity: only time-adjacent groups are considered contiguous and are assessed for clustering. The clustering algorithm is supplemented with a statistical test of cluster fusion, the hypothesis behind which is based on the ecological model of a succession evolving by steps (or disjunction model) (Allen et al. 1977). First, a distance matrix among samples, here using the Steinhaus similarity index (Legendre \& Legendre 1983), is computed. Given the contiguous groups $i$ and $j$ that are proposed for fusion by the clustering algorithm, a 1-tailed test is made for the null hypothe- sis that the 'large distances' in the sub-matrix are distributed at random between these 2 groups. The test is performed by randomisation. When the null hypothesis is accepted at the given confidence interval ( $\alpha$ level), the 2 groups are fused. Complementary information is derived from various $\alpha$ levels of clustering. The smallest $\alpha$ values show where the most important disjunctions in the succession took place, while larger $\alpha$ values bring out the finest structure of the successional events. Thus, the successional stages can be analysed at different temporal scales by selecting different $\alpha$ levels. We obtained similar and comparable segmentations in both layers, so we decided to present the results only for the sum-matrix (surface + middle).

Step 5. Definition of microplankton assemblages: To define statistical communities or assemblages a clustering of the species was made using the hierarchical flexible clustering method (Lance \& Williams 1967) with $b=-0.3$ on an Euclidean matrix of distances (Legendre \& Legendre 1983). Here again, similar assemblages were obtained for surface and middle samples, so the definition of microplankton assemblages was applied to the sum-matrix.

Step 6. Succession of microplankton assemblages: The algorithm of Deperieux et al. (1983) was applied to assess the representative of each assemblage in each period detected by the chronological clustering. By means of this algorithm a 'pattern variable' (or compound series) is constructed for each assemblage. Its value, at each period defined between disjunctions, corresponds to an averaged percentage. Each value for 1 descriptor is divided by the total abundance, following which all these percentages are added for all the species, and this sum is divided by the number of species of the corresponding group. One or several assemblages were considered characteristic for the period when positive high deviations of the pattern variable were detected, and vice versa.

Step 7. Summary: comparison between environmental disturbances, disjunctions in community structure and temporal changes in microplankton assemblages: The time-series of environmental and microplankton data were segmented by means of 2 different nonrelated statistical methods. The $D^{2}$ to the centroid (Step 2) recognised the strongest punctual changes of the environmental parameters (disturbances), while chronological clustering (Step 4) identified the disjunctions in the succession and the periods within which the composition of microplankton was statistically homogeneous. The succession of microplankton assemblages (Step 5), and its relationship with environmental disturbances, was analysed through the definition of pattern variables (Step 6). 


\section{RESULTS}

\section{Meteorological and hydrographic variability}

Inter-annual and seasonal scenario

The year 1991 was, within the context of the reference period, 1987 to 1995, an average year for runoff (Table 2). The mean of this year, X91, was not significantly different from the mean of the reference period, $\hat{X}[\Delta X=X 91-\hat{X}<2 \cdot \mathrm{CI}(\hat{X})]$. This criterion applies also to the hydrographic variables related with the continental freshwater inputs, mainly salinity and silicate. The differences between the means were significant, $\Delta \hat{X} \geq 2 \cdot \mathrm{CI}(\hat{X})$ for the other meteorological variables: 89 and $153 \mathrm{~m}^{3} \mathrm{~s}^{-1} \mathrm{~km}^{-1}$ for the upwelling index and the along-shore Ekman transport respectively, and $10 \mathrm{cal} \mathrm{cm}^{-2} \mathrm{~d}^{-1}$ for the incoming solar radiation. On an annual basis these 3 variables are slightly related: the Spearman rank-order correlation coefficients $\left(\mathrm{r}_{\mathrm{s}}\right)$ between the quarterly seasonally adjusted residuals of the 1987 to 1995 time-series were about

Table 2. Long-term context. Comparison between the means of the reference period 1987 to 1995 and the year 1991. For each variable, the difference between the means, $\Delta X=X 91-$ $\hat{X}$, was compared with the $95 \%$ confidence interval of the mean of the reference period, CI $(\hat{X})$. Only the year 1991 was considered for comparison with the reference period (i.e. $9 \mathrm{yr}$ overall) in order to avoid the bias introduced by a smaller number of samples taken in late spring and summer months when the whole analysed period is considered (variable definitions, see Table 1)

\begin{tabular}{|c|c|c|c|c|}
\hline & \multirow[t]{2}{*}{ Variable } & \multicolumn{2}{|c|}{$\begin{array}{l}\text { Reference period } \\
\text { (1987 to 1995) }\end{array}$} & \multirow{2}{*}{$\begin{array}{c}1991 \\
\text { Mean } \\
\text { X91 }\end{array}$} \\
\hline & & $\begin{array}{c}\text { Mean } \\
\hat{X}\end{array}$ & $\begin{array}{c}\text { CI } \\
(\hat{X})\end{array}$ & \\
\hline \multicolumn{5}{|c|}{ Meteorology } \\
\hline & $-Q x$ & -19 & 37 & 70 \\
\hline & Qy & -277 & 44 & -124 \\
\hline & Qs & 407 & 5 & 41 \\
\hline & $\mathrm{Qr}$ & 26.2 & 1 & 26.3 \\
\hline \multicolumn{5}{|c|}{ Hydrography } \\
\hline \multirow[t]{7}{*}{ Surface } & $\mathrm{S}$ & 34.13 & 0.22 & 34.22 \\
\hline & $\mathrm{T}$ & 15.30 & 0.20 & 14.65 \\
\hline & N4 & 1.87 & 0.16 & 1.96 \\
\hline & N3 & 2.97 & 0.33 & 3.99 \\
\hline & $\mathrm{P}$ & 0.51 & 0.02 & 0.50 \\
\hline & $\mathrm{Si}$ & 4.57 & 0.42 & 4.86 \\
\hline & $\mathrm{Cl}$ & 4.57 & 0.39 & 4.70 \\
\hline \multirow[t]{7}{*}{ Bottom } & $\mathrm{S}$ & 35.58 & 0.02 & 35.59 \\
\hline & $\mathrm{T}$ & 13.71 & 0.10 & 13.17 \\
\hline & N4 & 2.40 & 0.14 & 2.34 \\
\hline & N3 & 5.60 & 0.26 & 7.13 \\
\hline & $\mathrm{P}$ & 0.69 & 0.02 & 0.71 \\
\hline & $\mathrm{Si}$ & 6.53 & 0.22 & 6.54 \\
\hline & $\mathrm{Cl}$ & 1.71 & 0.19 & 1.65 \\
\hline
\end{tabular}

$0.4(\mathrm{p}<0.05, \mathrm{~N}=36$ ) (Nogueira 1998). Thus, the annual anomaly in 1991 meant a relative deviation towards northeasterly winds, which promote upwelling, associated with low cloudiness. The hydrographic variables related with upwelling, mainly temperature and nitrate, mirrored the observed annual anomaly. The differences between the means were -0.65 and $-0.54^{\circ} \mathrm{C}$ for surface and bottom temperatures and 1.02 and $1.53 \mu \mathrm{mol} \mathrm{kg}{ }^{-1}$ for surface and bottom nitrate. For ammonium, phosphate and chlorophyll a the differences between the means were non-significant.

Seasonal variation provides the context for a correct interpretation of environmental disturbances and their roles on microplankton community structure. Since the seasonality of the meteorological and hydrographic variables has been analysed in previous works (e.g. Nogueira et al. 1997a) we will not go into depth here. Table 3 summarises the most prominent features inferred from the time-series of the meteorological variables (Fig. 3) and the time-depth contours of the hydrographic variables (Fig. 4).

\section{Environmental disturbances}

The time-series of $D^{2}$ to the centroid for the different sets of environmental variables are shown in Fig. 5a-d. The values of the $D^{2}$ above the $5 \%$ level of the $K^{2}$ distribution (dotted lines in Fig. 5a-d) represent the disturbances. By re-examination of the raw data, the disturbances were related to prominent changes in meteorological boundary conditions, mixing regimes and nutrient status (Table 4).

The $D^{2}$ to the centroid of the meteorological variables (Fig. 5a) pointed out 14 disturbances. The most severe (those above the $1 \%$ level of the $K^{2}$ distribution) occurred in March, October and November 1991 (observation days [obs. d.] 184-186, 390-394, 448-452) and April and May 1992 (obs. d. 569-581). Meteorological disturbances persisted 1 to $5 \mathrm{~d}$. The only exception was the severe incidence in April and May 1992, which lasted $12 \mathrm{~d}$. The average frequency was about $9 \mathrm{yr}^{-1}$ (estimated over the whole period), but the disturbance regime varied between seasons. The highest frequency (ca $0.1 \mathrm{~d}^{-1}$ ) occurred during the autumn transition of the year 1991 (obs. d. 390-460). Disturbances occurring during the downwelling seasons 1990-91 (obs. d. 57-61, 129-134, 184-186) and 1991-92 (obs. d. 438-444, 448-452) were related to intense runoff pulses (Fig. 3d) associated with strong southwesterly winds (Fig. 3a,b, Table 4). Those during the upwelling season of 1991 pointed out deviations from the fairly stable seasonal pattern, due to strong southerly (obs. d. 214-215, 311) or northerly (obs. d. 390-394) winds, or an anomalous, strong, northerly 


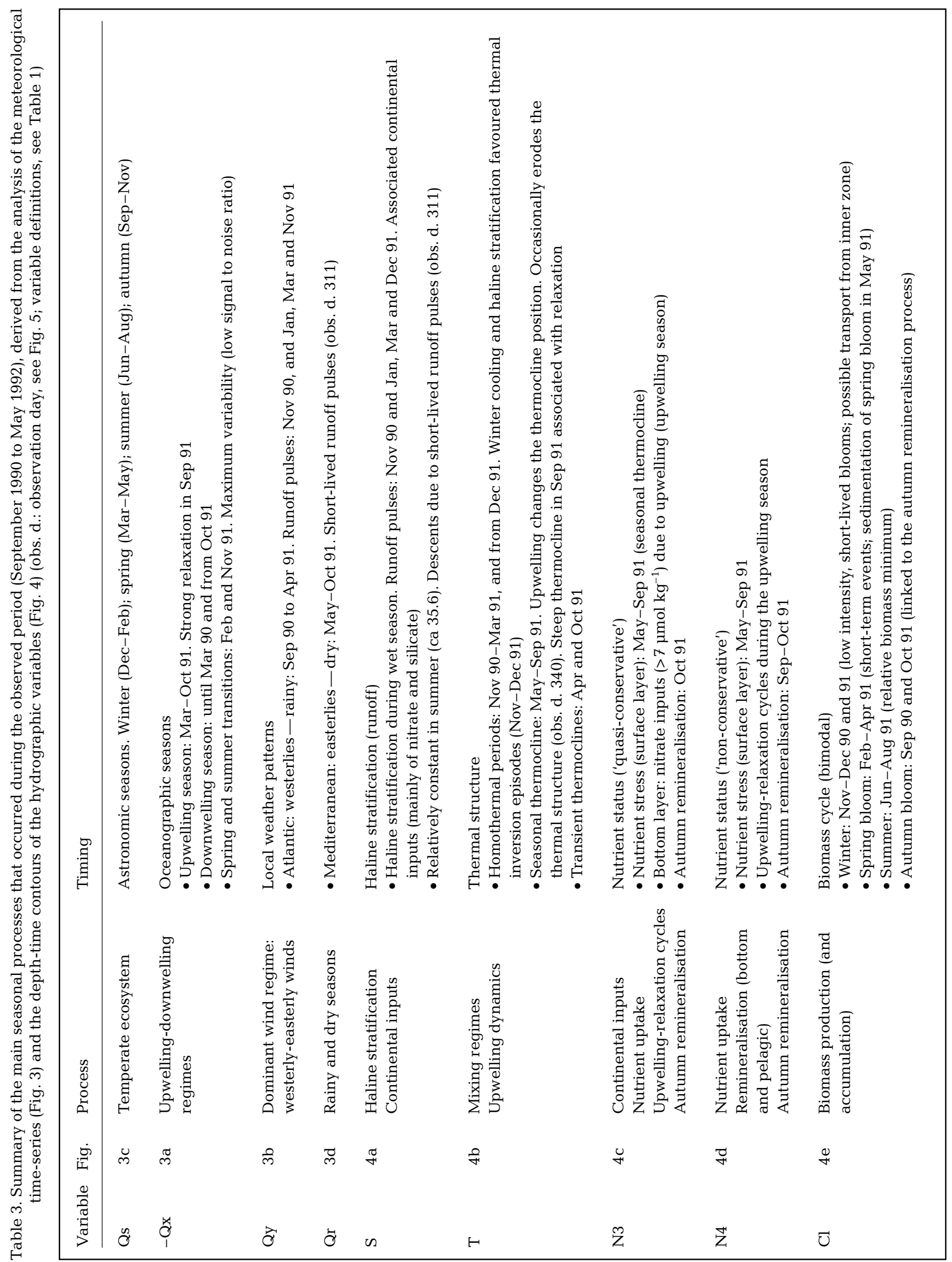




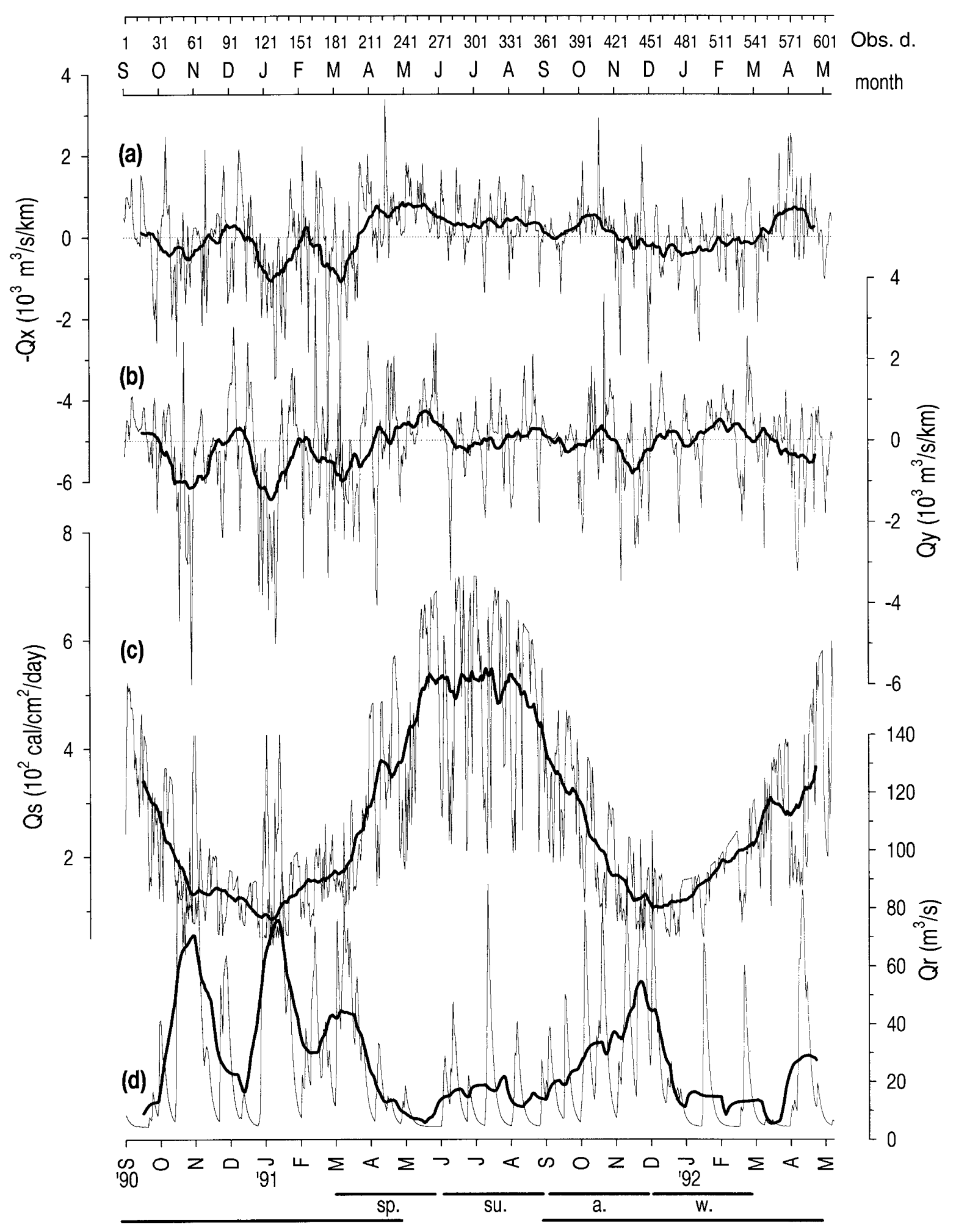

Fig. 3. Time-series of the meteorological variables; daily values and $30 \mathrm{~d}$ running mean: (a) upwelling index (-Qx); (b) alongshore Ekman transport (Qy); (c) incoming solar radiation (Qs); and (d) runoff in the drainage basin (Qr) 

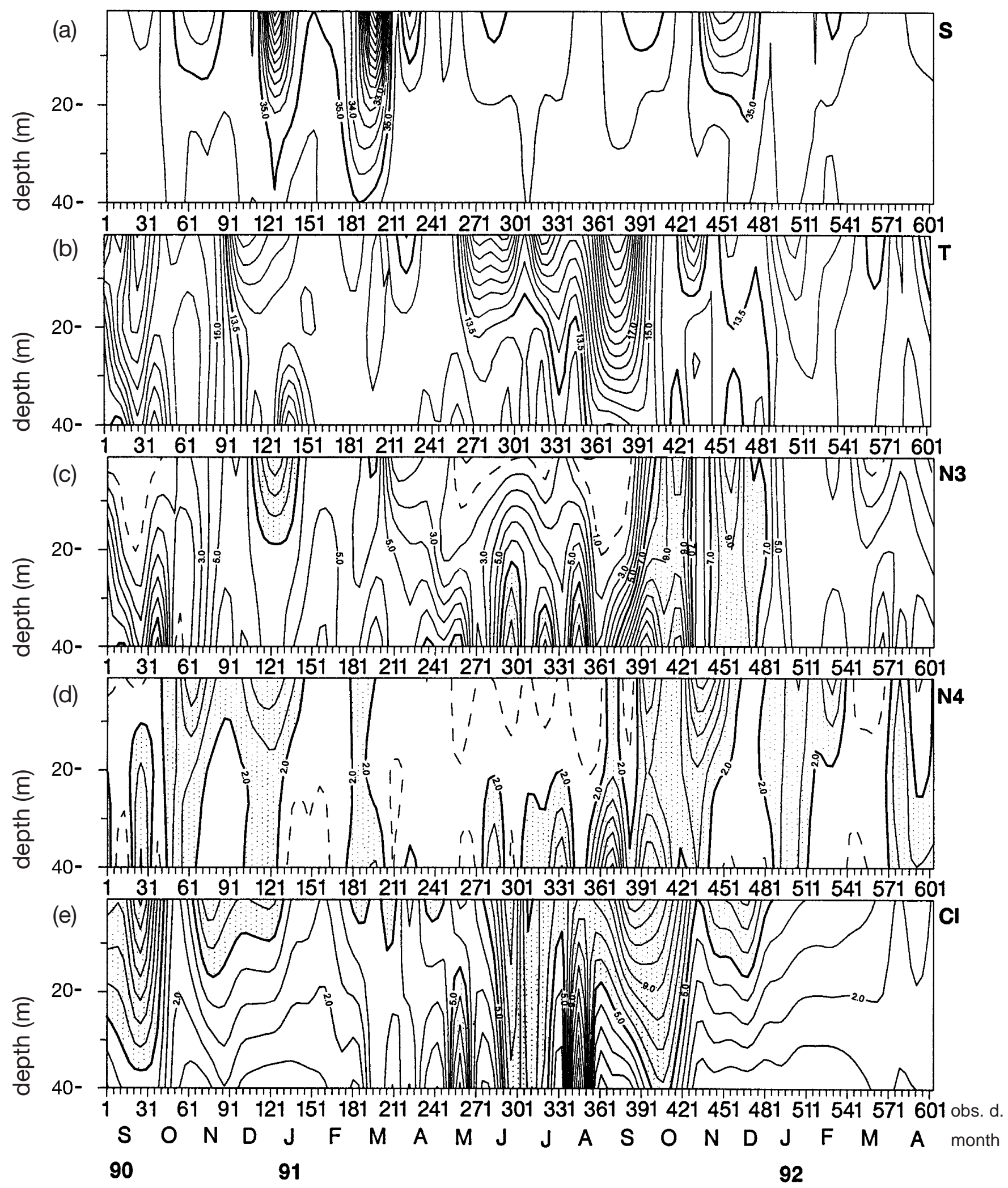

Fig. 4. Time-depth contours of selected hydrographic variables: (a) salinity (S); (b) temperature (T); (c) nitrate (N3); (d) ammonium (N4); and (e) chlorophyll a (Cl). The time-depth contours have been drawn using minimum curvature as the interpolating method 


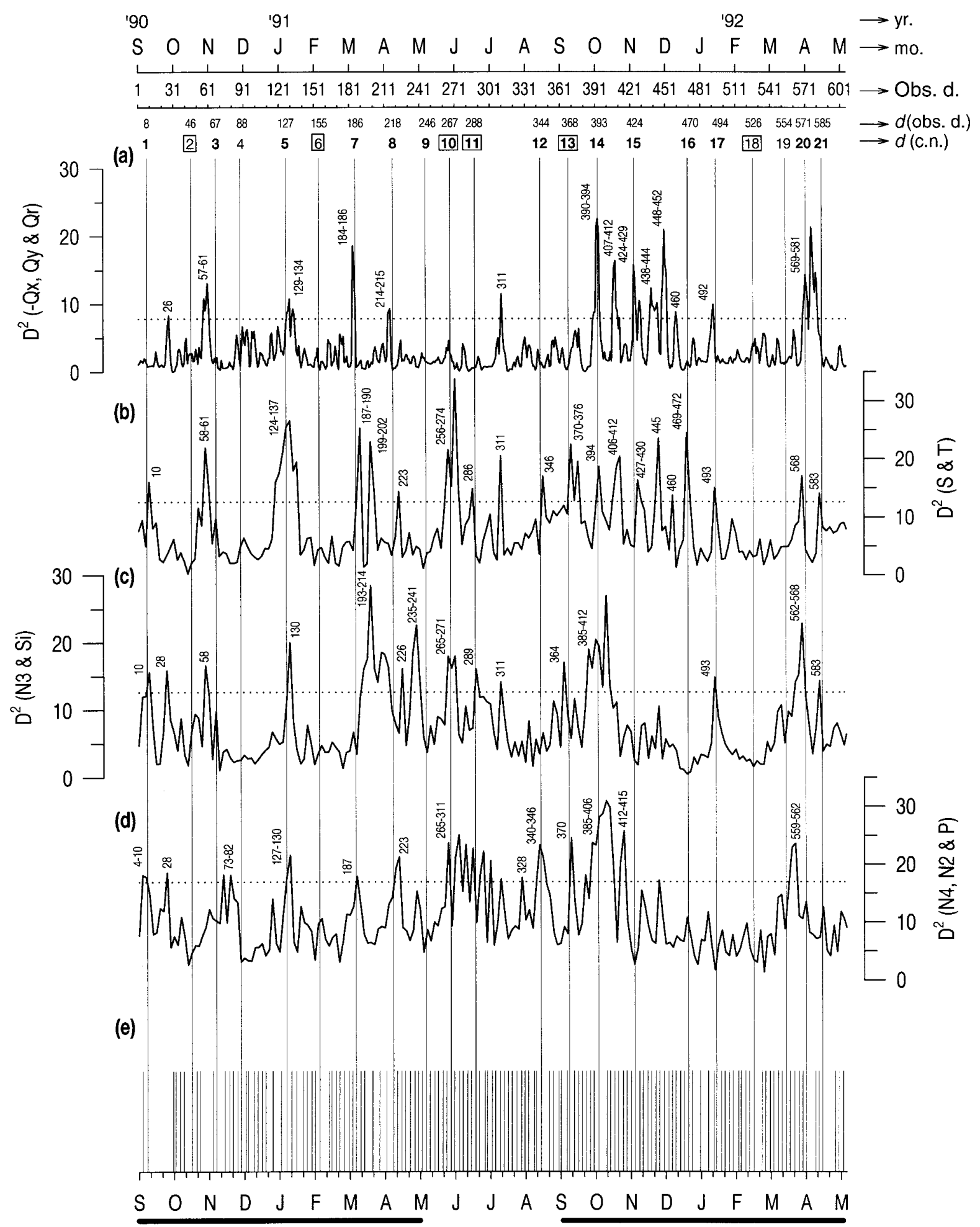

Fig. 5. $D^{2}$ to the centroid function for the different sets of environmental variables: (a) meteorological variables (-Qx, Qy and Qr); (b) thermohaline properties ( $\mathrm{S}$ and T); (c) nitrate-silicate fields (N3 and Si); and (d) ammonium-phosphate fields (N4 and P). The dotted horizontal lines represent the $5 \%$ level of the $K^{2}$ distribution; the values above these lines represent the disturbances, which are marked with the observation day(s) (obs. d.) on which they occurred. (e) Microplankton samples (vertical lines) and the disjunctions in the succession at the short-term scale $(\alpha=0.05)$ (longer vertical lines that cut the $D^{2}$ time-series). Disjunctions are coded from 1 to $21, d$ (c. n.); boxed-in codes refer to the longer time-scale $(\alpha=0.001)$ for which the observation day on which the disjunction occurred, d (obs. d.), is also indicated 


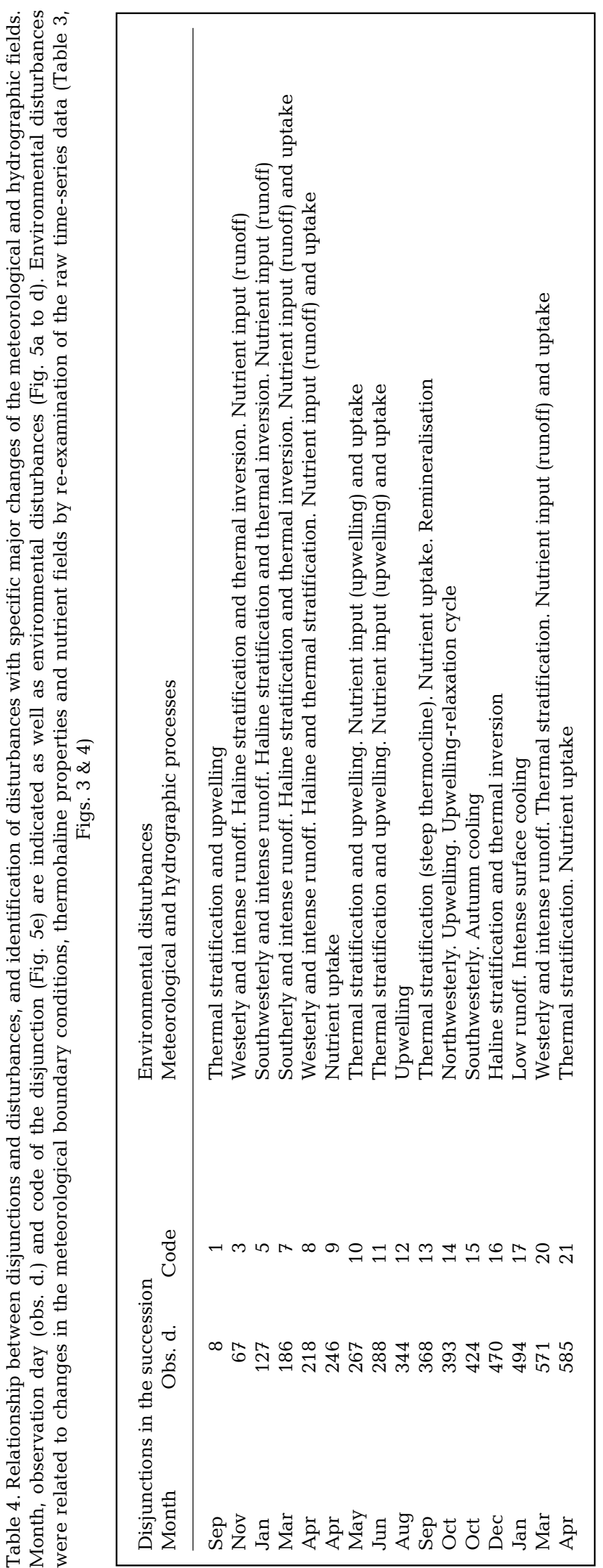

wind associated with high runoff (obs. d. 407-412). This last disturbance marked the beginning of the downwelling season of 1991/92. On a seasonal basis, the regime of disturbances during the downwelling seasons of 1990/91 and 1991/92 differed markedly.

The $D^{2}$ to the centroid detected 20 disturbances in the thermohaline fields (Fig. 5b), resulting in an average frequency of $12 \mathrm{yr}^{-1}$. Thermohaline disturbances were isolated events (obs. d. 311 or 346) but, generally, they persisted for at least 3 (e.g. obs. d. 58-61) and up to $13 \mathrm{~d}$ (obs. d. 124-137). They occurred every ca 15 d from September 1991 to January 1992 (between obs. d. 370 and 493), when meteorological variability was also more acute, and occurred less frequently, about once every 4 to $6 \mathrm{wk}$ for the rest of the analysed period.

During the downwelling seasons, most of the thermohaline disturbances were related to meteorological disturbances, while during the upwelling season the number of relationships declined (Fig. 5a,b). The correspondences took place, in any case, almost simultaneously or with a lag of several days. The disturbances recorded during the downwelling seasons were associated with episodes of haline stratification (Fig. 4a) due to runoff pulses (Fig. 3d), which favour thermal inversion when they occur during the cooling period (Table 3). The severe disturbance on obs. d. 256-274 marked the consolidation of the seasonal thermocline (Fig. 4b). During summer and early autumn (upwelling season), disturbances were associated with temperature variability due to coastal upwelling dynamics. For instance, disturbances on obs. d. 311 and 370-376 pointed out strong relaxation events that favoured the intensification of thermal stratification, while those on obs. d. 286 and 346 were associated with strong upwelling events. Disturbances on obs. d. 394 and 406-412 defined the end of the seasonal thermocline and were associated with strong mixing events.

Most of the 14 disturbances detected for the nitrate-silicate fields (Fig. 5c) were related with those of the thermohaline (and meteorological) variables. However, the disturbance regime presented some peculiarities. The major disturbances, in terms of amplitude and persistence, occurred in April (obs. d. 193-214), associated with continental input followed by nutrient uptake, and October (obs. d. 385-412), associated with a strong upwelling event followed by strong remineralisation (upwelling-relaxation cycle). Major disturbances were also detected on these observation days for the meteorological and thermohaline properties, although they were notably less persistent ( 1 to $3 \mathrm{~d}$ ). There was also an almost absence of disturbances from November 1991 to March 1992 (obs. d. 400-560). 
Disturbances of the ammonium-phosphate fields (Fig. 5d) showed a distribution similar to those of the nitrate-silicate fields, including the lack of disturbances between obs. d. 400 and 560 and the intensity and persistence of the major disturbance starting on obs. d. 385. The most distinctive features were the absence of disturbance in March 1991, at which time nitrate-silicate showed a severe one, and the highfrequency, short-lived disturbances at the beginning of summer (obs. d. 265-311).

\section{Microplankton community}

Temporal changes in microplankton community structure and its relationship with disturbances

The temporal changes in phytoplankton community structure (disjunctions) at different time-scales ( $\alpha$-level of clustering) are depicted in Fig. 5e. Their relationships with environmental disturbances are summarised in Table 4 . In the short-term $(\alpha=0.05), 21$ disjunctions were identified. They defined 22 time-groups in the multi-species time-series within which the composition of the community is statistically homogeneous. The duration of these time-groups was relatively alike (Table 4). The average duration was around $22 \mathrm{~d}$, and the maximum and minimum were 53 and $6 \mathrm{~d}$, corresponding to time-groups between disjunctions 11/12 (summer 1991) and 20/21 (spring 1992) respectively. At the smallest $\alpha$ value tested ( $\alpha=0.001), 6$ major disjunctions were detected (boxed-in numbers at the top of Fig. 5). The duration of the resultant 7 time-groups was more variable, the maximum duration being $146 \mathrm{~d}$ (between the major disjunction 13 to 18) and the minimum being $18 \mathrm{~d}(10 / 11)$. The importance of the major disjunctions is confirmed because no time-group expansion test covered them and they appeared in the entire range of $\alpha$ values tested (from 0.001 to 0.1 ).

Over the 21 short-term disjunctions, 16 coincided with a disturbance detected by the $D^{2}$ to the centroid method in at least 1 of the multivariate environmental time-series (Fig. 5, Table 4). These matches are marked by bold type numerals at the top of the microplankton disjunction lines in Fig. 5. More than half of the 14 disturbances of the meteorological variables coincided with disjunctions in the microplankton succession (disjunctions 3, 5, 7, 8, 14, 15, 17 and 20, Fig. 5a,e). The number of coincidences rose to 15 (ca $70 \%$ ) with disturbances of the thermohaline fields (disjunctions $1,3,5,7,8,10$ to 17,20 and 21).

For the nitrate-silicate fields, 9 disturbances coincided with disjunctions in the microplankton succession (disjunctions 1, 5, 9 to $11,13,14,17$ and 20). The same number of matches was identified in the case of disturbances of the ammonium-phosphate fields (disjunctions 1, 5, 7, 8 and 10 to 14). Almost all of the coincidences between disturbances of the nutrient fields and disjunction in microplankton succession were observed during the productive cycle.

Five disjunctions in the microplankton succession were not associated with environmental disturbances (disjunctions 2, 4, 6, 18 and 19). These took place during late autumn or winter. Disjunction 2 coincided with a period of strong southwesterly winds (both -Qx and Qy were negative, Fig. 3a,b) and strong runoff (Fig. 3d). Disjunction 4 coincided with the end of a runoff pulse (Figs. 3d \& 4a), and 6 and 18 occurred during an event of calm wind conditions (both - Qx and Qy were ca 0, Fig. 3a,b) and low runoff (Fig. 3d).

Among the 6 major disjunctions in the microplankton succession (disjunctions 2, 6, 10, 11, 13 and 18), those occurring in summer were associated with disturbances (disjunctions 10, 11 and 13), while the rest, which occurred in winter, were not.

\section{Microplankton assemblages}

Cluster analysis (Fig. 6) yielded 3 clusters at the $40 \%$ distance level (groups G1+G2, G3+G4 and G5+G6+ G7), and 7 clusters at the $20 \%$ level (sub-groups G1 to G7). Table 5 gives, for each sub-group, the mean equivalent spherical diameter, $\overline{\mathrm{ESD}}(\mu \mathrm{m})$, the mean surface to volume ratio, $\overline{s V^{-1}}\left(\mu m^{-1}\right)$, and the mean maximum photosynthetic growth rate, $\overline{\mu_{\max }}\left(\mathrm{d}^{-1}\right)$, calculated according to an allometric relationship (Nielsen \& Sand-Jensen 1990).

Cluster G5+G6+G7 is composed mainly of small diatoms with low $\overline{\mathrm{ESD}}$ and relatively high $\overline{s v^{-1}}$ and $\overline{\mu_{\max }}$ (Table 5). Some examples include Skeletonema costatum and Leptocylindrus danicus in G5, Guinardia delicatula and Nitzschia longissima in G7, and different species of the genus Chaetoceros that are represented all 3 sub-groups (Fig. 6). These species are considered typical representatives of r-strategists (Margalef 1958, Sommer 1981, Cushing 1989) or competitor (C) species (Reynolds 1997). The group includes some small autotrophic dinoflagellates (e.g. Gymnodinium nanum, G7) and flagellates (G6) which are also considered to possess the C-like characteristics of many organisms living in shallow coastal waters receiving high nutrient inputs (Reynolds \& Smayda 1998).

Cluster G1+G2, the most distant from G5+G6+G7, is composed mainly of motile dinoflagellates and ciliates, although some species of diatoms are also present (Guinardia striata, Rhizosolenia imbricata and Paralia sulcata in G2 and Pleurosigma elongatum and Coscinodiscus sp. in G1). Among the dinoflagellates, there are representatives of mixotrophic-autotrophic, e.g. 


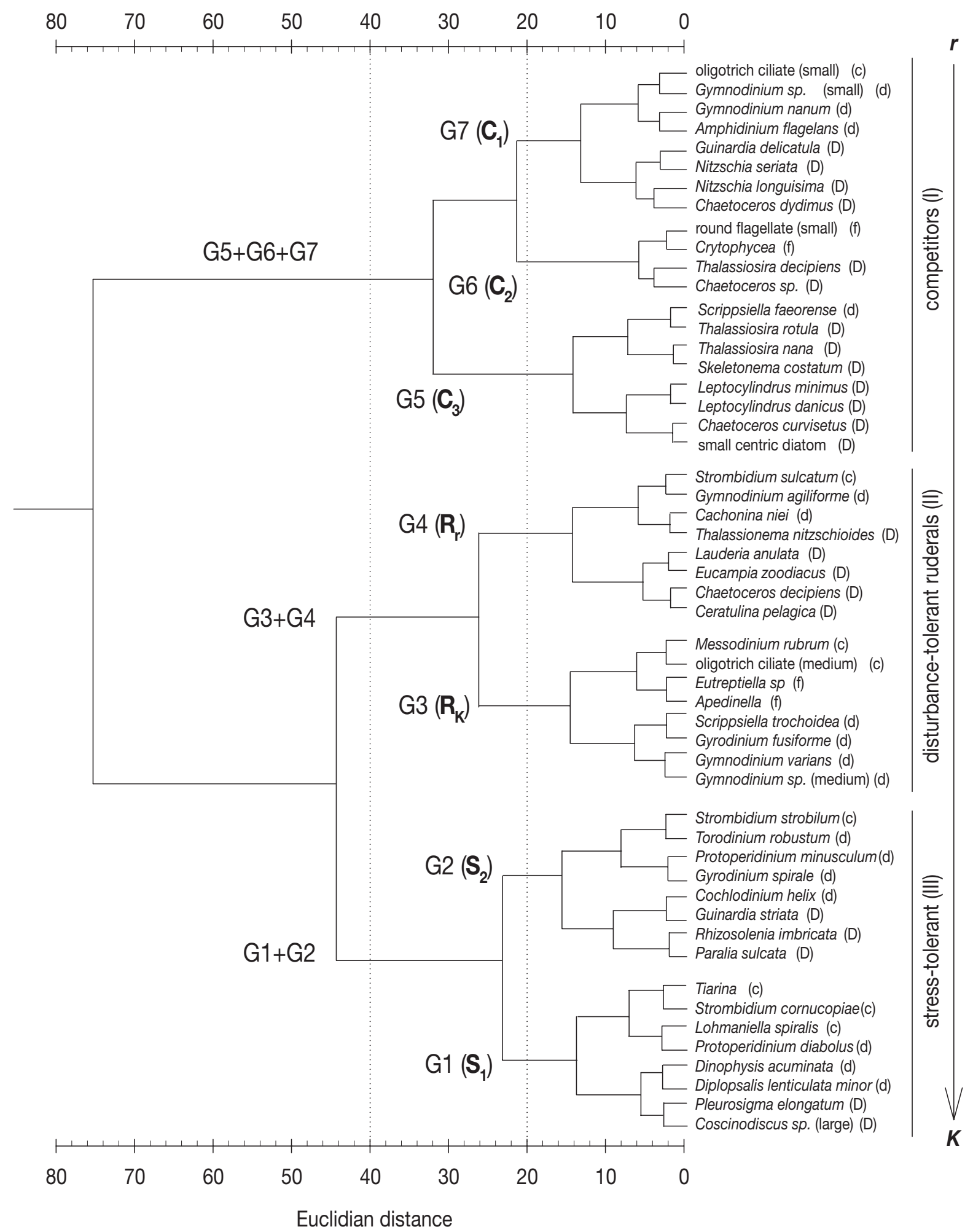

Fig. 6. Dendrogram of the Euclidean distance between species. The groups were re-named according to the gradient from $\mathrm{r}$ - to K-selected (see 'Results: Microplankton assemblages'). Letter in parentheses accompanying species name refers to the taxa (D, diatom; d, dinoflagellate; $\mathrm{c}$, ciliate; f, flagellate) 
Table 5. Mean equivalent spherical diameter ( $\overline{\mathrm{ESD}})$, mean surface to volume ratio $\left(\overline{s v^{-1}}\right)$ and mean maximal photosynthetic rate $\left(\overline{\mu_{\max }}\right)$ for each assemblage. The ESD for each assemblage is the geometric mean, $\overline{\mathrm{ESD}}=\sqrt{\mathrm{ESD}_{\max } \times \mathrm{ESD}_{\min }} \cdot \overline{s V^{-1}}$ and $\overline{\mu_{\max }}$ were estimated using the calculated ESD. The allometric relationship applied to the maximum photosynthetic rate is $\log \mu_{\max }=-3.80+0.66 \cdot \log \left(\overline{s V^{-1}}\right)($ Nielsen \& Sand-Jensen 1990)

\begin{tabular}{|lcrcc|}
\hline $\begin{array}{l}\text { Dendrogram } \\
\text { group }\end{array}$ & $\begin{array}{c}\text { Re-named } \\
\text { assemblage }\end{array}$ & $\begin{array}{c}\overline{\mathrm{ESD}} \\
(\mu \mathrm{m})\end{array}$ & $\begin{array}{c}\overline{s v^{-1}} \\
\left(\mu \mathrm{m}^{-1}\right)\end{array}$ & $\begin{array}{c}\overline{\mu_{\max }} \\
\left(\mathrm{d}^{-1}\right)\end{array}$ \\
\hline G7 & $\mathrm{C}_{1}$ & 11.0 & 0.544 & 0.97 \\
G6 & $\mathrm{C}_{2}$ & 7.4 & 0.811 & 1.26 \\
G5 & $\mathrm{C}_{3}$ & 11.4 & 0.528 & 0.95 \\
G4 & $\mathrm{R}_{\mathrm{r}}$ & 19.0 & 0.315 & 0.67 \\
G3 & $\mathrm{R}_{\mathrm{K}}$ & 19.8 & 0.303 & 0.66 \\
$\mathrm{G} 2$ & $\mathrm{~S}_{2}$ & 44.2 & 0.136 & 0.39 \\
G1 & $\mathrm{S}_{1}$ & 27.9 & 0.215 & 0.53 \\
\hline
\end{tabular}

Dinophysis acuminata (G1) and Cochlodinium helix (G2), and strictly heterotrophic species, e.g. Protoperidinium diabolus (G1) and Gyrodinium spirale (G2). The species of this group are relatively slow growing (Table 5). Most of the dinoflagellates and ciliates present in this assemblage are considered typical representatives of the stress-tolerant (S) or 'acquisitive' species (K-strategists) (Margalef 1958, Cushing 1989, Reynolds 1997).

Group G3+G4 occupies an intermediate position between the previously mentioned broad-scale groups according to its position in the dendrogram (Fig. 6) and allometric characteristics (Table 5). At the sub-group level, G3 and G4 have clearly distinct species compositions. Diatoms are not represented in sub-group G3, which is composed of dinoflagellates (e.g. Scrippsiella trochoidea, Gyrodinium fusiforme, Gymnodinium spp.), flagellates (Apedinella sp. and Eutreptiella sp.) and medium-size ciliates, including the autotrophic species Mesodinium rubrum. Medium-size diatoms, such as Lauderia annulata, Eucampia zoodiacus, Chaetoceros decipiens and Cerataulina pelagica form sub-group G4. Group G3+G4 corresponds to the ruderal (R) or 'attuning' species, which are particularly tolerant to physical perturbations, and to typical representatives of both K- and r-strategists. Species with a K-selected character, such as Apedinella sp. and Eutritella sp. (Harris 1978, Reynolds 1997), are represented in sub-group G3, while the r-selected species, such as the 'bitter' diatoms E. zoodiacus and L. annulata (Margalef 1958, Cushing 1989), are in G4.

The clusters defined phytoplankton assemblages with different replication strategies (sensu Reynolds 1997) and were arranged in the dendrogram according to a gradient from $r$ - to K-strategists (decreasing values of $\overline{\mu_{\max }}$ in Table 5). Accordingly, the sub-groups G1 to G7 were re-named (Fig. 6, Table 5). Clusters G7, G6 and G5 (competitors, C-species) were re-named $\mathrm{C}_{1}, \mathrm{C}_{2}$ and $\mathrm{C}_{3}$ respectively; $\mathrm{G} 4$ and $\mathrm{G} 3$ (ruderal, R-species), $\mathrm{R}_{\mathrm{r}}$ and $R_{K}$ (with subscripts indicating the $r$ - or K-strategy character of each cluster); and finally, G2 and G1 (stress-tolerant, $\mathrm{S}$-species), $\mathrm{S}_{2}$ and $\mathrm{S}_{1}$.

\section{Microplankton succession and replication strategies}

Pattern analysis (Step 6 in the numerical analysis, Fig. 2) was applied to represent the temporal changes in relative abundance of the different microplankton assemblages $\left(\mathrm{C}_{1}\right.$ to $\left.\mathrm{S} 1\right)$. Fig. 7 illustrates the changes of each assemblage according to the chronological segmentation (Fig. 5e).

The species that belong to the group of competitors $\left(\mathrm{C}_{1}+\mathrm{C}_{2}+\mathrm{C}_{3}\right)$ were more abundant during the productive part of the year, from spring to autumn. The abundance of the species of assemblage $C_{1}$ was relatively stable, although 2 periods of high abundance were distinguishable at the beginning of the analysed period (September to November 1990) and from spring to summer (April to August 1991). Assemblage $C_{2}$ showed a similar pattern to that of $\mathrm{C}_{1}$, although the species within $\mathrm{C}_{2}$ were the most abundant during the spring bloom in 1991. $\mathrm{C}_{3}$ presented the most characteristic pattern among competitors, with distinctive peaks in abundance during autumn (September and October 1990 and 1991) and relatively high abundance during most of the year 1991, from mid winter to late autumn (January to October).

The stress-tolerant group $\left(\mathrm{S}_{1}+\mathrm{S}_{2}\right)$ showed a betterdefined pattern. Both assemblages were clearly more abundant during summer months and early autumn of 1991 (June to October). The species within assemblage $\mathrm{S}_{2}$ showed a slight peak in abundance in spring 1991 (April and May), whereas the abundance of those in $\mathrm{S}_{1}$ peaked in the spring of 1992.

Among the ruderal species, the assemblage $R_{r}$ presented a fluctuating abundance pattern. The species of this assemblage were relatively more abundant during the autumn transitions (September to October 1990 and 1991) and winter (November to December 1990 and February to March 1992), but were poorly represented during the most productive part of the year, between spring and summer. The species of the $R_{K}$ assemblage fluctuated less than those of the $\mathrm{R}_{\mathrm{r}}$ assemblage. They showed 2 slight peaks in abundance during the spring (April to May 1991 and April 1992) and late summer (August to September 1991). They were relatively abundant during the first winter of the analysed period (December 1990 to January 1991) but almost absent in the second.

The main seasonal processes of the environmental variables and the seasonal succession of the different 


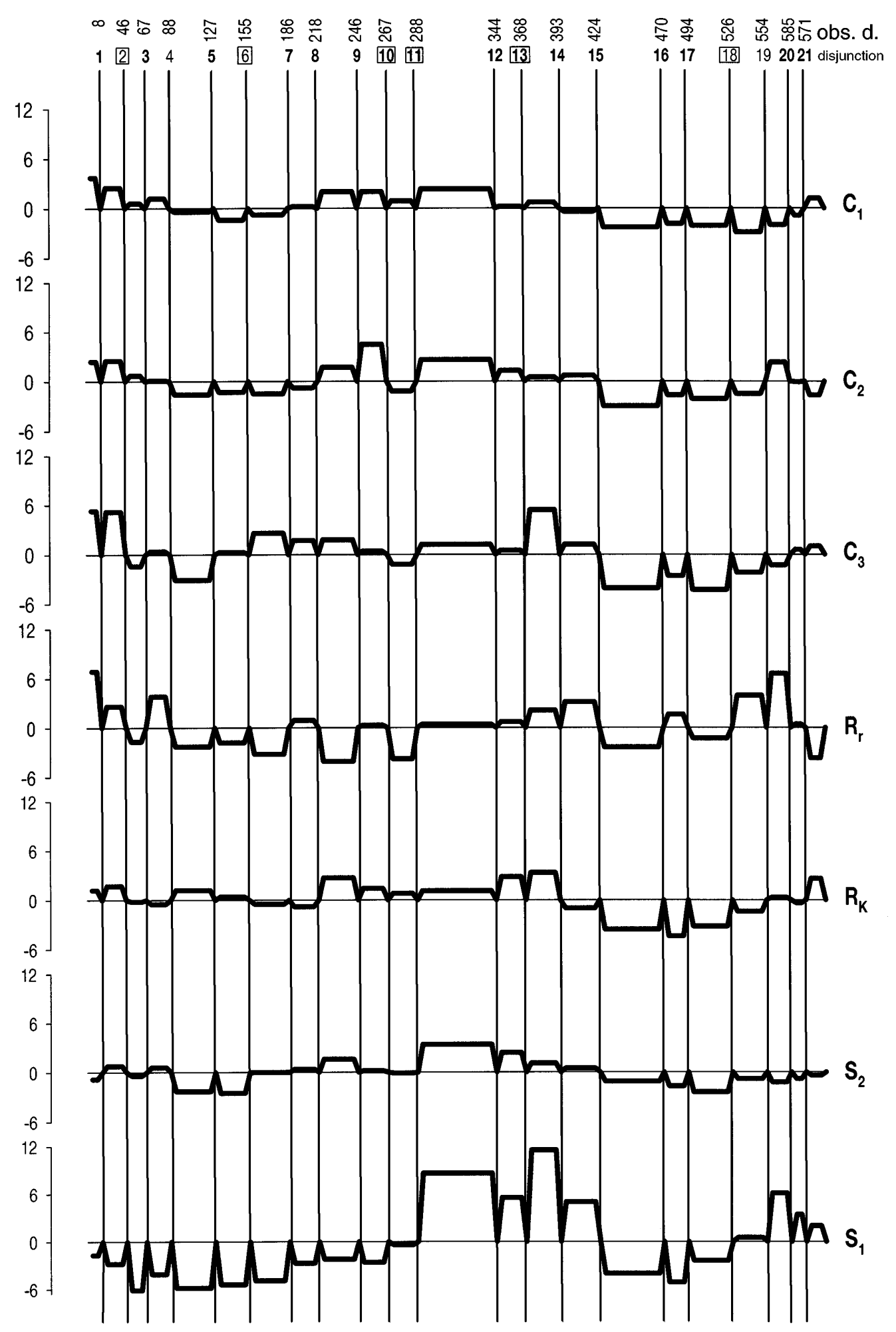

Fig. 7. Patterns of abundance of the phytoplankton assemblages according to the disjunctions in the succession. In the ordinate is given the logarithm of the standardised abundance of each assemblage. Ordinate 0 corresponds with the mean abundance of the assemblage, while positive or negative values indicate a relative increase or decrease of the assemblage over the mean abundance 
assemblages are represented in Fig. 8. In 1991, the seasonal sequence of the different microplankton assemblages followed in general terms the expected sequence from $\mathrm{r}$ - to K-selected species. The competitors appeared first. The species within assemblage $C_{3}$ increased their relative abundance at the end of winter (from disjunction 5), while assemblages $\mathrm{C}_{1}$ and $\mathrm{C}_{2}$ increased in the period of the transient thermoclines (from disjunction 8). The relative abundance of stresstolerant species $\left(\mathrm{S}_{1}\right.$ and $\left.\mathrm{S}_{2}\right)$ increased acutely when the seasonal thermocline was fully developed and the ecosystem entered a nutrient stress phase (from disjunction 11). However, a stage of competitive exclusion was not attained because the disturbances occurring during summer 1991 delayed the progress towards a 'climax' by allowing the maintenance of a relatively high abundance of competitor species. Although the fluctuating nature of ruderal species made it difficult to determine a clear seasonal pattern, these species seem to occupy an intermediate position along the sequence from $\mathrm{r}$ - to K-selected species.

A distinctive feature in the 1991 reproductive season was the drop in the relative abundance of all assemblages (except $\mathrm{S}_{1}$ ) between disjunctions 10 and 11 (Fig. 7). It is also worth mentioning the interannual differences associated with the onset and termination of the productive season (Fig. 8). The onset in 1991 was notably different from that in 1992; however, the termination in 1991 was abrupt compared with that of the year before.

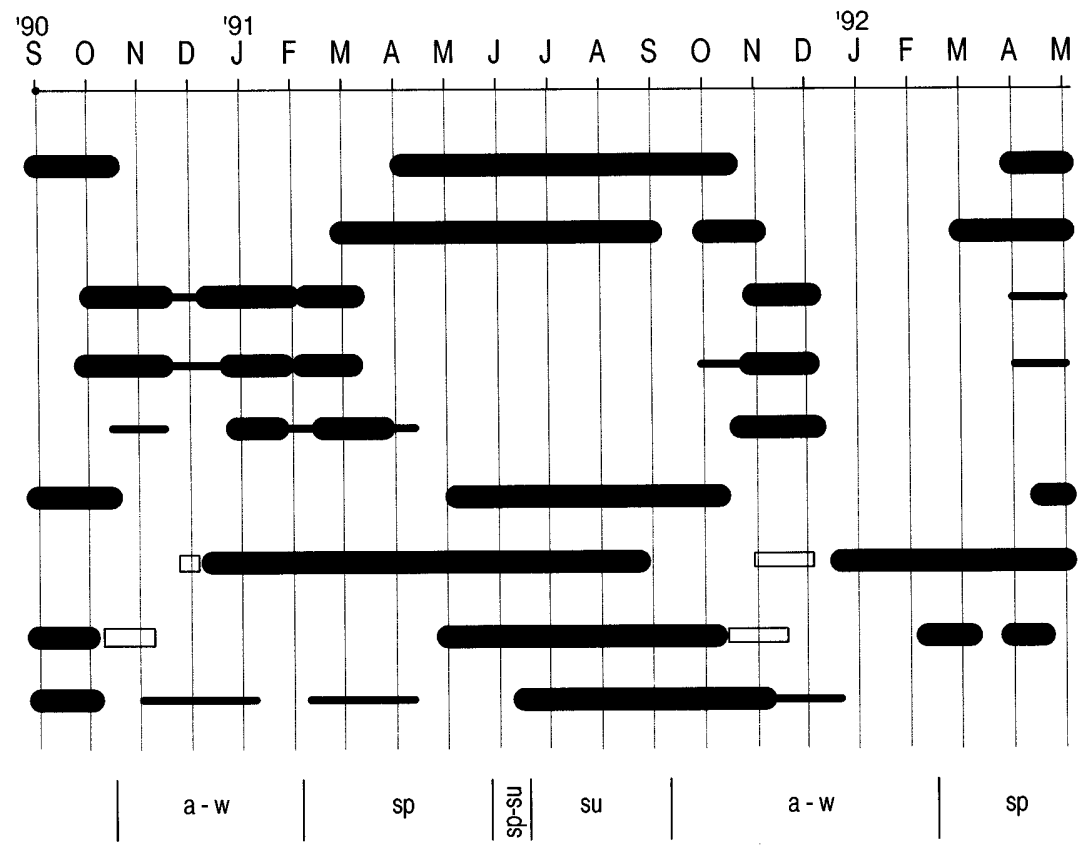

\section{seasonal processes}

temperate ecosystem (Qs $>400 \mathrm{cal} \mathrm{cm}^{-2} \mathrm{~d}^{-1}$ )

upwelling season $\left(-Q x>0 \mathrm{~m}^{3} \mathrm{~s}^{-1} \mathrm{~km}^{-1}\right)$

westerlies (Qy $>0 \mathrm{~m}^{3} \mathrm{~s}^{-1} \mathrm{~km}^{-1}$ )

runoff $\left(Q r>20 \mathrm{~m}^{3} \mathrm{~s}^{-1}\right)$

surface salinity $(\mathrm{Ss}<35)$ (haline stratification)

seasonal thermocline $\left(\Delta \mathrm{T}>3^{\circ} \mathrm{C}\right)$

bottom temperature $\left.\right|^{*}\left(\mathrm{~Tb}<13.5^{\circ} \mathrm{C}\right)$ winter cooling and * thermal inversion episodes ( $\square$ )

surface nitrate depletion and autumn regeneration $(\square)$

phytoplankton biomass (Chl-a)

seasonal changes in phytoplankton community according to major disjunctions

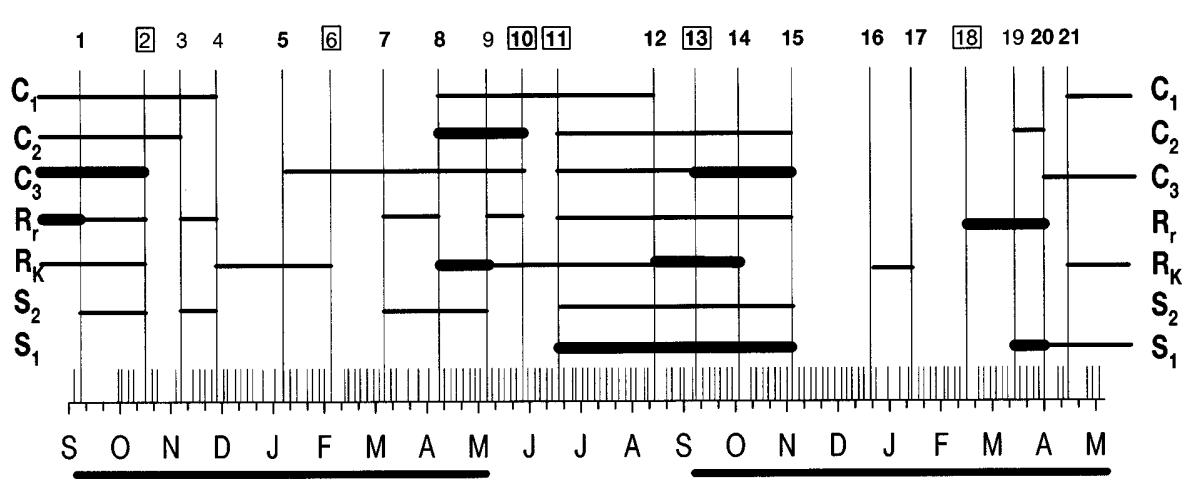

Fig. 8. Meteorological and hydrographic seasonal processes and microplankton succession. The upper panel shows the timing of the main seasonal meteorological and hydrographic processes relevant to phytoplankton dynamics. The lower panel shows the seasonal microplankton succession for the different assemblages; the horizontal bars indicate when the abundance of a given assemblage is above its total abundance value (pattern variable, Fig. 7); the microplankton samples and the disjunctions in the succession (Fig. 5e) are also shown 


\section{DISCUSSION}

\section{Detection and characterisation of disturbances}

One of the main problems in the analysis of successional phenomena concerns the identification and characterisation of disturbances (Reynolds et al. 1993). Since natural microplankton communities can react to different kinds of stimulus not always easily distinguishable, the difference between disturbances and stress is sometimes blurred (Padisák 1993) and the contribution of allogenic and autogenic factors difficult to assess. For instance, allogenic disturbances may trigger the response of the microplankton community through changes in the stratification-mixing regime, and therefore in the nutrient and light fields. The community response will modify in turn the pelagic environment through different processes. Communitydriven processes, such as corporate nutrient depletion, self-shading or grazing may impose a temporary stress-condition on the pelagic ecosystem (Reynolds 1993). The clear water phase (discussed below) shows an example of the tight relationship between allogenic and autogenic disturbances and stress.

Some studies have shown that there is no clear covariance between disturbances of a single factor and changes in community structure (some examples in Yodzis 1986). According to Padisák (1993), this constitutes an indirect indication that disturbances must be considered as a compound (multivariate) variable. The results that we have obtained by considering disturbances as compound variables (ca $70 \%$ of coincidences between thermohaline disturbances and disjunctions) support this idea. It is important to take into account the criteria applied to group the different environmental variables that are relevant to microplankton dynamics. Here, the criteria were based on hierarchical constraints, i.e. according to the causal sequence: meteorological $\rightarrow$ thermohaline $\rightarrow$ nutrient fields (Nogueira et al. 1997b, 1998), and time-scale considerations, i.e. exclusion of Qs from the meteorological fields and distinction of sets of nutrients according to their distinct degree of non-conservative behaviour (Liss 1976).

The Mahalanobis' distance, used in the auto- $D^{2}$ and in the $D^{2}$ to the centroid functions (Ibanez 1976, 1981), is particularly accurate in characterising multivariate series. The auto- $D^{2}$ function estimates the temporal dependence of a multivariate series. It represents a multivariate extension of the geostatistic function (semi-variogram) and is usually applied in geological sciences (e.g. Moline \& Bahr 1995). Here the auto- $D^{2}$ was used to estimate the observational window (Platt \& Denman 1975) to calculate the $D^{2}$ to the centroid function. Then, the $D^{2}$ to the centroid corresponds to the deviation of each observation for the local mean of observations lying in the window defined by the auto$D^{2}$. High values of the $D^{2}$ to the centroid for some observations represent 'multivariate outliers' that can be interpreted, on a statistical basis, as disturbances. It is also possible, for instance, to consider the general mean estimated with all the observations (e.g. Rojo \& Cobelas 1993), but as with kriging estimation, it is more suitable to consider the local structures. Besides, as disturbances vary seasonally (Padisák 1993), it is important to analyse them in an appropriate temporal context, defined here by the auto- $D^{2}$ function.

The good co-variance between disturbances and disjunctions suggests that the $D^{2}$ to the centroid method could be used as a prognostic tool to anticipate changes in community structure. In this direction, the most promising results were provided by the $D^{2}$ to the centroid time-series of thermohaline properties, as a proxy for stratification (haline and thermal vertical structure) and circulation processes. This result stresses the importance of hydrodynamic control in these estuarine upwelling ecosystems (Figueiras et al. 1994, 1995, Pazos et al. 1995). There is still room for improvement for the identification of hydrodynamic disturbances, for instance, by increasing the vertical (and temporal) resolution of the thermohaline fields (CTD profiles) and considering direct measurement of the velocity field (current-meters or ADCP measurements).

\section{Microplankton assemblages and replication strategies}

The classification technique applied to define microplankton assemblages rendered well-defined groups interpretable according to different replication strategies. Both the species composition of the groups (Margalef 1958, Harris 1978, Cushing 1989) and their allometric characteristics (Table 5) support this interpretation. The groups in the dendrogram were arranged according to a strategy-type gradient from $\mathrm{r}$ to K-selected (sensu Sommer 1981) or from C- through $\mathrm{R}$ - to S-selected (competitor, ruderals and stress-tolerant, sensu Reynolds 1997).

Although the concept of different reproduction strategies was introduced many years ago (MacArthur \& Wilson 1967), few studies have incorporated it explicitly in phytoplankton studies (Padisák et al. 1988). In the case of microplankton, reproduction strategy is tightly linked to cell size and, through allometric relationships, to eco-physiological properties such as nutrient uptake, respiration, light harvesting, sinking or differential grazing (e.g. Moloney \& Field 1989, Nielsen \& Sand-Jensen 1990, Kiørboe 1991, 1995). Since there is increasing evidence for the size-differential control of 
pelagic ecosystem structure (Dortch \& Packard 1989, Legendre \& Rassoulzadegan, 1996), application of the concept of replication strategies offers clear advantages for the interpretation of microplankton succession and its relationship with the fluxes of energy and matter in the ecosystem (Margalef 1961, Odum 1969). The transition from early to later successional stages (from r- to K-selected species) involves important changes in terms of community energetics (e.g. from linear to web-like food chains), structure (e.g. from low to high biochemical diversity), homeostasis (e.g. from low to high information content) or nutrient cycling (e.g. from open to close mineral cycles). Thus, the obtained groups have a direct reading in terms of functionality in the pelagic ecosystem. The concept of diversity, derived here from the analysis of pattern variables of different assemblages, was applied to associations of species sharing defined functional properties (Juhász-Nagy 1993, Reynolds 1993), so we were dealing with the analysis of diversity at the functional level.

\section{Roles of disturbances in community structure}

The first species that increased their abundance in 1991 (from disjunction 5) were those of assemblage $C_{3}$ (Fig. 7), represented almost exclusively by small diatoms (Fig. 6), the typical competitors, i.e. r-strategists. The group's characteristic high replication rate (Table 5) allowed the members to counteract losses due to intense vertical mixing and wash-out (reinforced 2-layered positive circulation pattern associated with runoff episodes, Table 4). They are also efficient light harvesters (Kiørboe 1995), able to cope with low, almost limiting (Qs $<150 \mathrm{cal} \mathrm{cm}^{-2} \mathrm{~d}^{-1}$, Fig. 3c) irradiance levels (Quéguiner \& Tréguer 1984). The dominance of the species of assemblage $\mathrm{C}_{3}$, mainly Skeletonema costatum, Thalassiosira nana, Leptocylindrus danicus and L. miniumus, over the other competitors $\left(C_{1}\right.$ and $\left.C_{2}\right)$ could be the result of a larger inoculum population for the initialisation of the succession (Reynolds 1997), since these species dominated the autumn bloom of the year before. In early spring (disjunction 7), again a disturbance associated with intense runoff (obs. d. 184-186) promoted the development of species associated with turbulent conditions, such as the bitter diatoms Lauderia annulata and Eucampia zoodiacus (in $\mathrm{R}_{\mathrm{r}}$ ) or the benthic diatom Paralia sulcata (in $\mathrm{S}_{2}$ ) (Figueiras \& Ríos 1993). However, since relatively few species can cope with the exigent environmental conditions prevailing during this period (January to March), mainly low irradiance and intense mixing and wash-out, functional diversity was relatively low.
Functional diversity increased during the period of the transient thermoclines (ca $50 \mathrm{~d}$ from disjunction 8 to 10). The response of the microplankton community can be related to the disturbance regime acting on the early stages of the succession. The combination of moderate wash-out (short-lived runoff pulse on obs. d. 214-215) and relative stability (reinforcement of thermal stratification on obs. d. 223) provoked an immediate response (Pádisak 1993, Reynolds 1993) and allowed the co-existence of competitors (the aforesaid species of $\mathrm{C}_{3}$ plus the diatoms Chaetoceros dydimus and Nitzschia longuissima and the small autotrophic dinoflagellate Gymnodinium nanum) and stress-tolerant (mainly G. varians and Apedinella sp. in $\mathrm{R}_{\mathrm{K}}$ and Protoperidinium minusculum in $\mathrm{S}_{2}$ ). Corporate nutrient depletion, identified as a disturbance of the nitrate and silicate fields between obs. d. 235 and 241 and associated with disjunction 9 (Table 4), favoured species with a stress-tolerant character $\left(R_{K}\right.$ and $\left.S_{2}\right)$, which, nevertheless, were unable to dominate through competitive exclusion due to the maintenance of moderate turbulence.

The consolidation of the thermocline (Fig. 4b), a cardinal event identified as a severe thermohaline disturbance on obs. d. 256-274, promoted at disjunction 10 (obs. d. 267) a notable decrease of r-selected species (C and $\mathrm{R}_{\mathrm{r}}$ ). Only stress-tolerant species $\left(\mathrm{S}\right.$ and $\mathrm{R}_{\mathrm{K}}$ ) showed a relative increase in abundance during this period (Fig. 7). This major disjunction in the succession, the clear water phase, seems to have being driven mainly by the nutrient stress condition imposed by the onset of the seasonal thermocline. In spite of its high nutrient harvesting efficiency, related to its high $s v^{-1}$, nutrient stress is a severe handicap for the maintenance of the elevated metabolic rates that characterise r-strategists (Moloney \& Field 1989). The sedimentation of the spring species has been suggested as a manifestation of the collapse of the populations caused by nutrient depletion (Cushing 1989) rather than through other autogenic processes such as grazing (e.g. Lampert et al. 1986). Such an episode occurred in the clear water phase of 1991, causing the bottom chlorophyll a peak at the end of May (Fig. 4e).

A short-lived upwelling event (disturbances of the thermohaline and nitrate-silicate fields around obs. $d$. 286, Fig. 5b,c) promoted an almost immediate response of the community (disjunction 11). Functional diversity attained the maximum value through a sharp increase in abundance of representatives of all replication strategists. Consideration of the time elapsed since the last disturbance and the intensity and persistence of the upwelling event are critical in understanding the event's effect on the community. The time elapsed ( $3 \mathrm{wk}$ ) was not enough to acutely eliminate competitors through sedimentation in the stratified conditions pre- 
vailing during the clear water phase (Lindenschmidt \& Chorus 1998). Therefore, enough stock remained to resume the growth of r-selected species when promoted by the mixing and nutrient replenishment associated with the upwelling event. On the other hand, the new hydrographic situation did not eliminate Kselected species. The number of generations within this period, 8 for a typical representative of the $S_{1}$ assemblage, did not lead to competitive exclusion (Reynolds 1993), but allowed the consolidation of the stress-tolerant species (Padisák 1993). The observed regime of allogenic disturbances promoted a major restructuring of the phytoplankton community, which modified in turn the pelagic environment, mainly the underwater irradiance (through chlorophyll concentration, Fig. 4e), but also the nutrient fields. The shortlived, high-frequency disturbances of the ammoniumphosphate fields reflect the sedimentation and bottom regeneration of spring species during the stratified conditions and the replenishment of new and regenerated (enrichment of the ENACW, Fraga 1981) nutrients associated with the upwelling event.

During summer, when the thermocline was fully developed and the surface layer became nutrient depleted, hydrographic disturbances related with upwelling-downwelling dynamics and occurring at intermediate frequency (every ca $20 \mathrm{~d}$ between disjunction 11 and 15) maintained C- and R-species and delayed the dominance of $\mathrm{S}$-species. The period between disjunction 11 and 12 was fairly stable and lasted long enough to allow competitive exclusion to occur. However, the disturbance on obs. d. 311 (Fig. 5a-d), an intense short-term downwelling and runoff event, could have been influential enough to maintain r-selected and delay the dominance of $\mathrm{K}$ selected species. The characteristic group during this period was $\mathrm{S}_{1}$, represented by typical stress-tolerant species generally included in summer assemblages, such as the heterotrophic dinoflagellate Protoperidinium diabolus and the mixotrophic-autotrophic dinoflagellate Dinophysis acuminata, a red-tide species associated with DSP (diarrhetic shellfish poisoning) outbreaks. The inclusion of Coscinodiscus spp., a genus of large diatoms usually associated with winterspring assemblages and turbulent conditions (Figueiras \& Ríos 1993), may be related to the strong upwelling conditions which, on an annual basis, prevailed during 1991 (Nogueira et al. 1997a). The number of generations involved within the relatively stable periods defined between disturbances was about 10 (according to $\mu_{\max }$ of $\mathrm{S}$-species in Table 5), lower than the theoretical number of 12 to 16 generations (Reynolds 1993), or 35 to $60 \mathrm{~d}$ (Sommer 1985), required for competitive exclusion to occur. Consequently, functional diversity remained high throughout the course of allogenic disturbances occurring at intermediate frequencies.

The abundance decrease of all assemblages (except $\mathrm{R}_{\mathrm{r}}$ ) began at disjunction 14 and was promoted by a strong upwelling event which eroded the thermocline that had been weakened by the progression of seasonal surface cooling (Fig. 4b). This strong mixing event also promoted a major change in the nutrient fields, which showed a more intense and persistent disturbance over the analysed period (obs. d. 385-412). The disturbances of the nutrient fields pointed out the autumn regeneration; at the height of this season, the upwelling event mobilised ammonium derived from the remineralisation of the particulate organic matter that had progressively been accumulated during the productive cycle. The seasonal succession finished abruptly in the last week of October; the abundance of all assemblages showed an important decrease after disjunction 15, in response to disturbances associated with intense mixing driven by downwelling and autumnal cooling (Table 4). Disturbance 15 also marked the onset of the anomalous downwelling season of 1991/92 (Nogueira 1998), characterised by its relatively low runoff associated with irregular, weak westerly winds and a high frequency of meteorological and, consequently, hydrographic disturbances. It is uncertain how this anomalous weather pattern influenced the abrupt collapse of the succession or the low abundance of competitors in comparison with the same period the year before, but there is ample evidence that interannual weather variability has a profound impact on the community composition (Colebrook \& Tavlor 1984, Aebischer et al. 1990). For instance, the relatively low intensity and persistence of runoff may not have been enough to trigger the response of competitors by means of temporary haline stratification and continental nutrient input and/or provide the inoculum from the inner ría. Nutrient inputs associated with runoff episodes promoted changes in community structure that were especially significant in the early stages of the seasonal succession of 1991, by promoting the increase in abundance of competitors, mainly diatoms. The fact that continental inputs in the Ría de Vigo are silicate-rich (Pérez et al. 1992), through weathering of the granite rock which is the main constituent of the drainage basin, stresses the importance of runoff events in the initialisation of the succession by diatoms.

\section{Conclusions}

The numerical methods (Fig. 2) were suited to discern and quantify different kinds of stimuli and to relate them to the response of the microplankton com- 
munity at the assemblage, i.e. functional, level. By means of a separate characterisation of environmental disturbances and community structure we overcame the main problems associated with the analysis of disturbances and their roles in microplankton community structure.

The pelagic ecosystem was disturbed at intermediate frequencies (ca $10 \mathrm{yr}^{-1}$ ) in relation to the microplankton generation times. Disturbances of the thermohaline fields promoted changes in community structure, stressing the importance of hydrodynamic control in this ecosystem. During the productive part of the year, disturbances of the nutrient fields were associated to some extent with internally driven processes.

Microplankton assemblages were interpreted in terms of different replication strategies: well-defined groups of competitors, ruderals and stress-tolerant species were discerned. The seasonal succession of assemblages progressed from r- to K-selected strategists. Species with an r-selected character (C-groups and $\mathrm{R}_{\mathrm{r}}$ ) dominated during the onset of new hydrographic conditions (e.g. transient thermoclines), while $\mathrm{K}$-species (S-groups and $\mathrm{R}_{\mathrm{K}}$ ) dominated under stratified conditions (e.g. seasonal thermocline).

The progress of functional diversity and its relationship with the disturbance regime operating at a given successional stage supports the predictions of the IDH. In the early stages of the succession, the community responded almost immediately to disturbances. However, functional diversity was low since only rapidgrowth species (C- and $\mathrm{R}_{\mathrm{r}}$-species) can cope with the prevailing environmental conditions, mainly intense vertical mixing and wash-out associated with runoff episodes. The onset of the seasonal thermocline, and the associated nutrient stress condition, promoted the development of specialist species ( $\mathrm{S}$ - and $\mathrm{R}_{\mathrm{K}}$-species) that have complex adaptations to compete for depleted extrabiotic resources. However, a state of competitive exclusion was not attained. Allogenic disturbances occurring at intermediate frequencies delayed the dominance of stress-tolerant species and allowed the maintenance of competitors and ruderals; therefore, high functional diversity was preserved through the co-existence of all replication strategies.

Acknowledgements. The authors thank the members of the Grupo de Oceanoloxía of the Instituto de Investigación Mariñas who collaborated in the sampling. Special thanks go to A. M. Mosquera for evaluating the phytoplankton. The Instituto Español de Oceanografía supplied the Ekman transport components. The Instituto Nacional de Meteorología monitored cloudiness and precipitation values. This study was supported by the EU project MAST-CT90-0017 'The control of phytoplankton dominance'. E.N. acknowledges the Xunta de Galicia, which financed his stage at Villefrance-sur-Mer, and the receipt of a Marie Curie post-doctoral fellowship from the EU. The collaboration of F.I. was made possible by the Programme National Environnement Côtièr (PNEC) topic variabilité spatio-temporelle, évolution et tendances à long terme.

\section{LITERATURE CITED}

Aebischer NJ, Coulson C, Colebrook JM (1990) Parallel longterm trends across four trophic levels and weather. Nature 347:753-755

Allen TFH, Koonce JF (1973) Multivariate approaches to algal stratagems and tactics of system analysis of phytoplankton. Ecology 54:1234-1246

Allen TFH, Bartell SM, Koonce JF (1977) Multiple stable configurations in ordination of phytoplankton community change rates. Ecology 58:1076-1084

Álvarez-Salgado XA, Rosón G, Pérez FF, Figueiras G, Pazos Y (1996) Nitrogen cycling in an estuarine upwelling system, the Ría de Arousa (NW Sapin). I. Short time-scale patterns of hydrodynamic and biogeochemical circulation. Mar Ecol Prog Ser 135:259-273

Bakun A (1973) Coastal upwelling indices, west coast of North America, 1946-71. NOAA (Natl Ocean Atmos Adm) Tech Rep NMFS (Natl Mar Fish Serv) 671:1-103

Blasco D, Estrada M, Jones BH (1980) Short term variability of phytoplankton populations in upwelling regions - the example of North West Africa. In: Richards FA (ed) Coastal and estuarine science 1. Coastal upwelling. American Geophysical Union, Washington, DC, p 339-347

Colebrook JM, Taylor AH (1984) Significant time scales of long-term variability in the plankton and the environment. Rapp PV Réun Cons Int Explor Mer 183:20-26

Connell JH (1978) Diversity in tropical rain forest and coral reefs. Science 199:1302-1310

Cooley WW, Lohnes PR (1962) Multivariate procedures for the behavioural sciences. J Wiley \& Sons, New York

Cushing DH (1989) A difference in structure between ecosystems in strongly stratified waters and in those that are only weakly stratified. J Plankton Res 11(1):1-13

Deperieux E, Feytmans E, Micha JC (1983) Utilisation critique de l'analyse en composantes principales et du cluster analysis pour la description d'échantillons d'invertebrés benthiques en eau douce. Oikos 40:81-94

Dietrich G, Kalle K, Krauss W, Siedler G (1980) General oceanography: an introduction, 2nd edn. J Wiley \& Sons, New York

Dortch Q, Packard TT (1989) Differences in biomass structure between oligotrophic and eutrophic marine ecosystems. Deep-Sea Res 36(2):223-240

Falkowski P, Kiefer DA (1985) Chlorophyll-a fluorescence in phytoplankton: relationships to photosynthesis and biomass. J Plankton Res 7:715-713

Figueiras FG, Pazos Y (1991) Microplankton assemblages in three Rías Baixas (Vigo, Arosa and Muros, Spain) with a subsurface chlorophyll maximum: their relationships to hydrography. Mar Ecol Prog Ser 76:219-233

Figueiras FG, Ríos AF (1993) Phytoplankton succession, red tides and the hydrographic regime in the Rías Bajas of Galicia. In: Smayda TJ, Shimizu Y (eds) Toxic phytoplankton blooms in the sea. Elsevier, New York, p 239-244

Figueiras FG, Jones KJ, Mosquera AM, Álvarez-Salgado XA, Edwards A, MacDougall N (1994) Red tide assemblage formation in an estuarine upwelling ecosystem: Ría de Vigo. J Plankton Res 16:857-878

Figueiras FG, Wyatt T, Álvarez-Salgado XA, Jenkinson IR (1995) Advection, diffussion and patch development in the 
Rías Baixas. In: Lassus P, Arzul G, Erard E, Gentien P, Marcaillou C (eds) Harmful marine algal blooms. Technique et Documentation - Lavoisier, Intercept Ltd, Paris, p 579-584

Fraga F (1981) Upwelling off the Galician coast, northwest Spain. In: Richards FA (ed) Coastal and estuarine science 1. Coastal upwelling. American Geophysical Union, Washington, DC, p 176-182

Fraga F (1996) As Rías. In: Consello da Cultura Galega (ed) As Augas de Galicia, Vigo, p 215-260

Grime JP (1979) Plant strategies and vegetation processes. Wiley-Interscience, Chichester

Hansen HP, Grasshoff K (1983) Automated chemical anakysis. In: Grasshoff K, Ehrhadt M, Kremling K (eds) Methods of seawater analysis, 2nd edn. Verlag Chemie, Weinheim, p 347-395

Harris GP (1978) Photosynthesis, productivity and growth the physiological ecology of phytoplankton. Arch Hydrobiol Beih Ergeb Limnol 10:1-171

Harris GP (1986) Phytoplankton ecology: structure, function and fluctuation. Chapman and Hall, USA

Ibanez F (1976) Contribution à l'analyse mathématique des événements en écologie planctonique. Bull Inst Océanogr (Monaco) 1-96

Ibanez F (1981) Immediate detection of heterogeneities in continuous multivariate, oceanographic recordings. Application to time-series analysis of changes in the bay of Villefranche sur Mer. Limnol Oceanogr 26:336-349

Ibanez F, Dauvin JC, Ettienne M (1993) Comparison des évolutions à long-terme (1977-1990) de deux peuplements macrobenthiques de la baie de Morlaix (Manche Occidentale): relations avec les facteurs hydroclimatiques. J Exp Mar Biol Ecol 16:181-214

Juhász-Nagy P (1993) Notes on compositional diversity. Hydrobiologia 249:173-18

Karentz D, Smayda TJ (1998) Temporal patterns and variations in phytoplankton community organization and abundance in Narraganset Bay during 1959-1980. J Plankton Res 20(1):145-168

Kiørboe T (1991) Pelagic fisheries and spatio-temporal variability in zooplankton production. Bull Plankton Soc Jpn Spec Vol:229-249

Kiørboe T (1995) Turbulence, phytoplankton cell size, and the structure of pelagic food webs. Adv Mar Biol 29:1-72

Kjerfve B, Proehl JA, Schwing FB, Seim HE, Marozas M (1982) Temporal and spatial considerations in measuring estuarine water fluxes. In: Kennedy VS (ed) Estuarine comparisons. Academic Press, New York, p 37-51

Lampert W, Fleckner W, Rai H, Taylor BE (1986) Phytoplankton control by grazing zooplankton: a study on the clearwater phase. Limnol Oceanogr 31(3):478-490

Lancaster P, Salkaukas K (1986) Curve and surface fitting. Academic Press, London

Lance GN, Williams WT (1967) Mixed-data classificatory programs. I. Agglomerative systems. Aust Comput J 1:15-20

Legendre L, Legendre P (1983) Numerical ecology. Elsevier Scientific Publishing Company, Amsterdam

Legendre L, Rassoulzadegan F (1996) Food-web mediated export of biogenic carbon in oceans: hydrodynamic control. Mar Ecol Prog Ser 145:179-193

Legendre P, Dallot S, Legendre L (1985) Succession of species within a community: chronological clustering, with applications to marine and freshwater zooplankton. Am Nat 125(2):257-288

Lewis MR, Platt T (1982) Scales of variability in estuarine ecosystems. In Kennedy VS (ed) Estuarine comparisons. Academic Press, New York, p 37-51
Lindenschmidt KE, Chorus I (1998) The effect of water column mixing on phytoplankton succession, diversity and similarity. J Plankton Res 20(10):1927-1951

Liss PS (1976) Conservative and non-conservative behaviour of dissolved constituents during estuarine mixing. In: Burton JD, Liss PS (eds) Estuarine chemistry. Academic Press, New York, p 93-130

MacArthur RH, Wilson EO (1967) The theory of island biogeography. Princeton University Press, Princeton, NJ

Margalef R (1958) Temporal succession and spatial heterogeneity in phytoplankton. In: Buzzato-Traverso AA (ed) Perpectives in marine biology. University of California Press, Berkeley, CA, p 323-349

Margalef R (1961) Communication of structure in plankton populations. Limnol Oceanogr 6:124-128

Margalef R (1968) Perspectives in ecological theory. University of Chicago Press, Chicago

Margalef R, Duran M, Saiz F (1955) El fitoplankton de la ría de Vigo de enero de 1953 a marzo de 1954. Invest Pesq 2:83-131

McClain CR, Chao SY, Atkinson LP, Blanton JO, Castillejo F (1986) Wind driven upwelling in the vicinity of Cape Finisterre, Spain. J Geophy Res 91(C7):8470-8486

Moline GR, Bahr JM (1995) Estimating spatial distributions of heterogeneous subsurface characteristics by regionalized classification of electrofacies. Math Geol 27:3-22

Moloney CL, Field JG (1989) General allometric equations for rates of nutrient uptake, ingestion, and respiration in plankton organisms. Limnol Oceanogr 34(7):1290-1299

Nielsen SL, Sand-Jensen K (1990) Allometric scaling of maximal photosynthetic growth rate to surface/volume ratio. Limnol Oceanogr 35(1):177-181

Nogueira E (1998) Análisis y modelado de la variabilidad temporal de las características hidrográficas en la Ría de Vigo. $\mathrm{PhD}$ thesis, Universidad de Vigo, Dep Física Aplicada

Nogueira E, Pérez FF, Ríos AF (1997a) Seasonal patterns and long-term trends in an estuarine upwelling ecosystem (Ría de Vigo, NW Spain). Estuar Coast Shelf Sci 44:285-300

Nogueira E, Pérez FF, Ríos AF (1997b) Modelling thermohaline properties in an estuarine upwelling ecosystem (Ría de Vigo, NW Spain) using Box-Jenkins transfer function models. Estuar Coast Shelf Sci 44:685-702

Nogueira E, Pérez FF, Ríos AF (1998) Modelling nutrients and chlorophyll a time series in an estuarine upwelling ecosystem (Ría de Vigo, NW Spain) using the Box-Jenkins approach. Estuar Coast Shelf Sci 46:267-286

Odum EP (1969) The strategy of ecosystem development. Science 164:262-270

Padisák J (1993) The influence of different disturbance frequencies on the species richness, diversity and equitability of phytoplankton in shallow lakes. Hydrobiologia 249:135-156

Padisák J, Reynolds CS, Sommer U (eds) (1993) Intermediate disturbance hypothesis in phytoplankton ecology. Kluwer Academic, Dordrecht (Reprinted from Hydrobiologia 249)

Pazos Y, Figueiras FG, Álvarez-Salgado XA, Rosón G (1995) The control of succession in red tide species in the Ría de Arousa (NW Spain) by upwelling and stability. In: Lassus P, Arzul G, Erard E, Gentien P, Marcaillou C (eds) Harmful marine algal blooms. Technique et DocumentationLavoisier, Intercept Ltd, Paris, p 645-650

Pérez FF, Álvarez-Salgado XA, Róson G, Ríos AF (1992) Carbonic-calcium system, nutrients and total organic nitrogen in continental runoff to the Galician Rías Baixas, NW Spain. Oceanol Acta 15(6):595-602

Pianka ER (1970) On r- and K-selection. Am Nat 104: 592-597

Picket STA, Kolasa J, Armesto JJ, Collins SL (1989) The eco- 
logical concept of disturbance and its expression at various hierarchical levels. Oikos 54:129-136

Platt T, Denman KL (1975) Spectral analysis in ecology. Annu Rev Ecol Syst 6:189-210

Quéguiner B, Tréguer P (1984) Studies on the phytoplankton in the Bay of Brest (Western Europe). Seasonal variations in composition, biomass and production in relation to hydrological and chemical features (1981-1982). Bot Mar 27:449-459

Reynolds CS (1993) Scales of disturbance and their roles in plankton ecology. Hydrobiologia 249:151-171

Reynolds CS (1997) Vegetation processes in the pelagic: a model for ecosystem theory. In: Kinne O (ed) Excellence in ecology. Ecology Institute, Oldendorf/Luhe

Reynolds CS, Smayda TJ (1998) Principles of species selection and community assembly in the phytoplankton: further explorations of the Mandala. In: Reguera B, Blanco J, Fernández ML, Wyatt T (eds) Harmful algae. Xunta de Galicia and Intergovernmental Oceanographic Commission of UNESCO, p 8-10

Reynolds CS, Padisák J, Sommer U (1993) Intermediate disturbance in the ecology of phytoplankton and the maintenance of species diversity: a synthesis. Hydrobiologia 249: 183-188

Ríos AF, Nombela MA, Pérez FF, Rosón G, Fraga F (1992) Calculation of runoff to an estuary. Ría de Vigo. Sci Mar 56: 29-33

Rojo C, Cobelas MA (1993) Hypertrophic phytoplankton and

Editorial responsibility: John Austin (Assistant Editor),

Oldendorf/Luhe, Germany the intermediate disturbance hypothesis. Hydrobiologia 249:43-57

Rosón G, Álvarez-Salgado XA, Pérez FF (1997) A non stationary box model to determine residual fluxes in a partially mixed estuary, based on both thermohaline properties. Application to the Ría de Arousa (NW Spain). Estuar Coast Shelf Sci 44:249-262

Sommer U (1981) The role of r- and K-selection in the succession of phytoplankton in Lake Constance. Acta Oecol 2: $237-342$

Sommer U (1985) Comparisons between steady state and non-steady state competitions: experiments with natural phytoplankton. Limnol Oceanogr 30:335-346

Sommer U, Pádisak J, Reynolds CS, Juhász-Nagy P (1993) Hutchinson's heritage: the diversity-disturbance relationship in phytoplankton. Hydrobiologia 249:1-7

UNESCO (1983) Algorithms for computation of fundamental properties of sea water. UNESCO Tech Pap Mar Sci 44: $1-53$

Utermöhl H (1958) Zur Vervollkommung der quantitativen Phytoplankton-Methodik. Mitt Int Verein Theor Angew Limnol 9:1-38

Wooster WS, Bakun A, McClain DR (1976) The seasonal upwelling cycle along the eastern boundary of the North Atlantic. J Mar Res 34(2):131-141

Yodzis P (1986) Competition, mortality and community structure. In: Diamond J, Case JT (eds) Community ecology. Harper and Row, New York, p 480-491

Submitted: October 28, 1999; Accepted: January 14, 2000

Proofs received from author(s): August 1, 2000 